\title{
The emerging role of probiotics as a mitigation strategy against coronavirus disease 2019 (COVID-19)
}

\author{
Rasoul Mirzaei ${ }^{1,2} \cdot$ Adeleh Attar $^{3} \cdot$ Saher Papizadeh $^{4} \cdot$ Ali Salimi Jeda $^{5} \cdot$ Seyed Reza Hosseini-Fard ${ }^{6}$. \\ Elaheh Jamasbi ${ }^{7}$. Sima Kazemi ${ }^{1}$. Saman Amerkani ${ }^{4}$. Gholam Reza Talei ${ }^{8}$. Pouya Moradi ${ }^{9} \cdot$ Saba Jalalifar $^{10}$. \\ Rasoul Yousefimashouf ${ }^{1,11} \cdot$ Mohammad Akhter Hossain $^{12} \cdot$ Hossein Keyvani ${ }^{5,13} \cdot$ Sajad Karampoor $^{5,13}$ (1)
}

Received: 3 November 2020 / Accepted: 28 January 2021 / Published online: 20 March 2021

(c) The Author(s), under exclusive licence to Springer-Verlag GmbH Austria, part of Springer Nature 2021, corrected publication 2021

\begin{abstract}
COVID-19 is an acute respiratory infection accompanied by pneumonia caused by severe acute respiratory syndrome coronavirus 2 (SARS-CoV-2), which has affected millions of people globally. To date, there are no highly efficient therapies for this infection. Probiotic bacteria can interact with the gut microbiome to strengthen the immune system, enhance immune responses, and induce appropriate immune signaling pathways. Several probiotics have been confirmed to reduce the duration of bacterial or viral infections. Immune fitness may be one of the approaches by which protection against viral infections can be reinforced. In general, prevention is more efficient than therapy in fighting viral infections. Thus, probiotics have emerged as suitable candidates for controlling these infections. During the COVID-19 pandemic, any approach with the capacity to induce mucosal and systemic reactions could potentially be useful. Here, we summarize findings regarding the effectiveness of various probiotics for preventing virus-induced respiratory infectious diseases, especially those that could be employed for COVID-19 patients. However, the benefits of probiotics are strain-specific, and it is necessary to identify the bacterial strains that are scientifically established to be beneficial.
\end{abstract}

Handling Editor: Sheela Ramamoorthy.

Mohammad Akhter Hossain

akhter.hossain1980@gmail.com

$\triangle$ Hossein Keyvani

keyvani.h@iums.ac.ir

$\triangle$ Sajad Karampoor

sajadkarampour1987@gmail.com

1 Department of Microbiology, School of Medicine, Hamadan University of Medical Sciences, Hamadan, Iran

2 Student Research Committee, Hamadan University of Medical Sciences, Hamadan, Iran

3 Department of Microbiology and Virology, School of Medicine, Zanjan University of Medical Sciences, Zanjan, Iran

4 Department of Microbiology and Virology, School of Medicine, Kerman University of Medical Sciences, Kerman, Iran

5 Department of Virology, School of Medicine, Iran University of Medical Sciences, Tehran, Iran
6 Department of Clinical Biochemistry, School of Medicine, Tehran University of Medical Sciences, Tehran, Iran

7 Department of Anatomical Sciences, Kermanshah University of Medical Science, Kermanshah, Iran

8 Department of Virology, School of Medicine, Lorestan University of Medical Sciences, Khorramabad, Lorestan, Iran

9 Department of Virology, Faculty of Medical Sciences, Tarbiat Modares University, Tehran, Iran

10 Department of Microbiology, School of Medicine, Iran University of Medical Sciences, Tehran, Iran

11 Research Center for Molecular Medicine, Hamadan University of Medical Sciences, Hamadan, Iran

12 The Florey University of Neuroscience and Mental Health, University of Melbourne, Melbourne, VIC 3010, Australia

13 Gastrointestinal and Liver Diseases Research Center, Iran University of Medical Sciences, Tehran, Iran 


\section{Introduction}

Respiratory infections (RIs) cause high morbidity and mortality globally. The viruses most frequently responsible for these infections include influenza viruses (IVs), coronaviruses, respiratory syncytial virus (RSV), parainfluenza viruses (PIVs), adenoviruses, and rhinoviruses (RVs) [14, 142]. The severity of viral respiratory infections varies widely, and severe disorders mostly occur in children and older adults [184]. Fatalities are often observed following a viral infection, which can be exacerbated by underlying conditions or coinfection of the paranasal sinuses, middle ear, or lungs [184]. Most importantly, an outbreak of SARS-CoV-2, which causes the disease COVID-19, was initially reported in China in December 2019 and quickly spread worldwide [124, 126, 127, 170]. By December 16, 2020 , the virus had caused 71,581,532 confirmed cases and 1,618,374 deaths worldwide [137]. Currently, there are no highly effective drugs for treatment of COVID-19 $[57,124,125,128]$. Consequently, it is crucial to discover alternative and safe approaches to reduce the risk of this infection.

Currently, some probiotics have been reported to prevent and alleviate bacterial and viral infections (VIs) [84]. Most of our findings regarding the reinforcement of immune reactions by probiotics have been from in vivo investigations. For instance, intranasal inoculation of mice with Lactobacillus reuteri and Lactobacillus plantarum has shown protective effects against lethal viral pneumonia [84]. The expected outcome of probiotic treatment in human investigations includes alleviation of diarrhea in infants and reduction of the severity of milk allergy in children and irritable bowel syndrome [44]. Probiotics likely affect mucosae by adjusting the microbiota, hindering the growth of pathogens, and increasing local and systemic immune reactions [68].

Regarding the advantages of probiotics in viral diseases, particular probiotic strains have been found to be efficient in reducing the duration and severity of gastroenteritis caused by rotaviruses [56]. More importantly, there is increasing evidence that probiotics are beneficial in the control of viral respiratory infections [97, 178]. Recent immunological studies have provided a better understanding of the role of innate immune responses and subsequent adaptive immune responses in the recognition and eradication of viral infections. For instance, it has been found that the production of type 1 interferons (IFNs) mainly mediates the control of viral infection, immune pathology, and the management of inflammatory cytokines via Tolllike receptors and retinoic-acid-inducible gene I [129, 158, 180]. Several studies have elucidated the immunostimulatory effects of probiotic bacteria and have described their capability to prevent VIs $[3,13,100]$. Accordingly, probiotic administration may be effective in reducing and/ or blocking SARS-CoV-2 infection, which has caused an enormous health and economic burden. This review describes current preventive and curative trial studies based on the use of probiotics against viral respiratory tract infections. We then outline the possible application of probiotic bacteria as a prophylactic approach against COVID-19.

\section{Viral respiratory infections}

The respiratory tract (upper or lower) is affected by many VIs $[34,169]$. These infections are clinically categorized based on the type of infection (e.g., bronchiolitis, common cold, pneumonia), and not based on the type of causative agent (influenza) [34, 169]. Although particular viral pathogens generally cause characteristic clinical outcomes (e.g., respiratory syncytial virus causes bronchiolitis, while rhinoviruses cause the common cold), each pathogen can cause viral respiratory syndromes $[8,146]$. The severity of viral respiratory disorders varies widely, and severe disorders are more likely to occur in children and older adults [31, 175, 186]. In most cases, respiratory viral infections are limited to the upper parts of the respiratory tract, where they induce relatively mild symptoms such as runny nose and sneezing [145]. Nevertheless, in susceptible individuals such as the elderly and newborns, infection can affect the lower respiratory airways, leading to wheezing, bronchiolitis, shortness of breath, and pneumonia [31, 175, 186]. Common respiratory viral pathogens include RSV, metapneumovirus, PIVs, bocaviruses, adenoviruses, IVs, RVs, and coronaviruses [14, 85].

Recent developments in virology have led to the development of standardized diagnostic techniques and the discovery of novel respiratory viruses such as influenza virus A (IVA), influenza virus B (IVB) and novel human coronaviruses (HCoVs) with the ability to cause a pandemic [214]. In contrast to the regular seasonal outbreaks of influenza, pandemics occur irregularly. For example, the so-called Spanish influenza pandemic in 1918 was the worst in recorded history and was responsible for about 50-100 million deaths [161, 179]. The influenza pandemic in 2009 was caused by IVA (H1N1) and is believed to have caused 100,000 to 400,000 deaths [35]. Coronaviruses are a large family of viruses with a broad range of hosts (humans and animals). Sometimes, an animal coronavirus can shift its host specificity, allowing it to infect humans $[41,199]$. Several well-known human coronaviruses, including 229E, NL63, OC43, and KHU1, have emerged recently and induce mild-to-moderate RIs such as the common cold [212]. However, SARS-CoV-1 and Middle East respiratory syndrome coronavirus (MERS-CoV) can 
cause critical RIs, and in 2003, the SARS-CoV-1 outbreak infected 8098 people, causing 774 deaths, while from 2012 to 2019, MERS infected 2494 people, causing 858 deaths [141]. SARS-CoV-2, which was first discovered in China, has caused an ongoing worldwide pandemic and, by October 1,2020 , this virus was responsible for 33,842,281 confirmed cases and 1,010,634 deaths worldwide [137].

\section{Immune reactions and pathogenesis of COVID-19}

It has been found that in severe cases of SARS-CoV-2 disease, the number of naive $\mathrm{T}$ helper (Th) lymphocytes increases while the number of memory Th lymphocytes and CD28 ${ }^{+}$T lymphocytes decreases $[150,190]$. The balance between memory $\mathrm{T}$ lymphocytes and naïve $\mathrm{T}$ lymphocytes is essential for proper host immune reactions [160]. Additionally, decreased numbers of natural killer (NK) cells and B lymphocytes have been observed in SARS-CoV-2 infection $[107,185]$. Another important finding is the documented association between inflammatory signs, such as IL-6 production, erythrocyte sedimentation, and C-reactive protein induction [193]. Although the proportion of $\mathrm{CD} 4^{+} / \mathrm{CD} 8^{+} \mathrm{T}$ lymphocytes in COVID-19 patients is usually the same as in uninfected subjects, an elevation of this ratio and a decreased proportion of $\mathrm{CD} 8^{+} \mathrm{T}$ lymphocytes and $\mathrm{B}$ lymphocytes have been suggested as predictors of poor outcome in follow-up [190, 193].

After the virus enters a cell, viral antigens are given to antigen-presenting cells (APCs), and this step is crucial in antiviral immunity [104]. The histocompatibility complex (MHC or human leukocyte antigen [HLA]) presents the viral antigen (antigenic peptide) to specific cytotoxic T lymphocytes (CTLs) [104]. Therefore, understanding SARS-CoV-2 antigen presentation will help researchers better understand COVID-19 pathogenesis [104]. So far, our information about SARS-CoV-2 is incomplete, and most of our current knowledge is from earlier investigations on SARS-CoV-1 and MERS-CoV. MHC I, rather than MHC II, is the source of SARS-CoV-1 antigen presentation to CTLs $[104,108]$. Previous research has shown a correlation of HLA polymorphisms such as HLA-B*4601, HLA-B*0703, HLA-DR B $1 * 1202$, and HLA-Cw*0801, with susceptibility to SARS-CoV-1 infection. In contrast, some alleles, such as HLA-DR0301, HLA-Cw1502, and HLA-A*0201, have been linked to protection against SARS-CoV-1 disease [104]. MHC II is correlated with host susceptibility to MERS-CoV disease (such as HLA-DRB1*11:01 and HLA-DQB1*02:0) [66]. It has also been shown that a mannose-binding lectin polymorphism is correlated with an increased risk of SARSCoV-1 infection [183]. These investigations provide significant insights into for COVID-19 pathogenesis.
Antigen presentation initiates the induction of adaptive immunity (humoral and cellular responses via virus-specific $\mathrm{B}$ and T cells) [104]. As in other acute VIs, typical IgM and $\mathrm{IgG}$ responses are generated against SARS-CoV-1 [104]. The specific IgM produced against SARS-CoV-1 disappears at the end of week 12. In contrast, the $\operatorname{IgG}$ antibody can persist for a longer period, suggesting its potential protective role. The $\mathrm{S}$ and $\mathrm{N}$ proteins of SARS-CoV-1 are primary targets for the production of specific IgGs [40, 101, 104]. Compared to humoral responses, more studies have been conducted on cellular immunity against coronaviruses. Recent analysis of the peripheral blood of SARS-CoV2-infected subjects has demonstrated reduced numbers of $\mathrm{CD}^{+}$and $\mathrm{CD}^{+} \mathrm{T}$ cells. Similarly, a significant reduction in $\mathrm{CD} 4^{+}$and $\mathrm{CD} 8^{+} \mathrm{T}$ cells is correlated with the acute phase of SARS-CoV-1 infection [104]. Even in the absence of antigens, $\mathrm{CD} 4^{+}$and $\mathrm{CD} 8^{+}$memory $\mathrm{T}$ cells can persist for four years in some SARS patients, with T cell propagation, DTH reactions, and IFN- $\gamma$ generation [49]. A specific memory T cell response to the SARS-CoV-1 S peptide could still be observed in 14 out of 23 recovered patients, even six years after infection [177]. Regarding MERS-CoV, specific CD8 ${ }^{+}$ $\mathrm{T}$ cell responses are responsible for clearing this virus in mice [215]. These findings might provide a basis for developing appropriate therapeutic approaches for treating SARSCoV-2 infections.

\section{Potential mechanisms of action of probiotics in prevention of respiratory viral infections}

Probiotics are live microorganisms that confer a health benefit on the host [50]. They commonly affect the innate and adaptive immune responses and can reduce the severity of disease in various disorders, including respiratory tract infections [73, 98, 140]. Recently, some probiotics were found to exert their immunomodulatory effect through their components, such as peptidoglycan, lipoteichoic acid, nucleic acid, which stimulates Toll-like receptors, and muramyl dipeptide, which stimulates Nod-like receptors [147]. Immune modulation occurs through regulatory $\mathrm{T}$ cells, type 3 innate lymphoid cells, and Th17 cells by recognizing the probiotic strain or its components and its effect on mucosal immunity $[58,84,143]$. The mechanism of action of probiotics in VIs is not entirely appreciated. However, it has been suggested that bacterial probiotics might bind to viruses, thus hindering viral binding to the host receptor [84]. Overall, the following mechanisms have been proposed for the effects of probiotics on viral respiratory infections (Fig. 1):

- Direct effect by a trapping strategy

- Activation of the immune reactions by interleukins, NK cells, Th1, and IgA production 


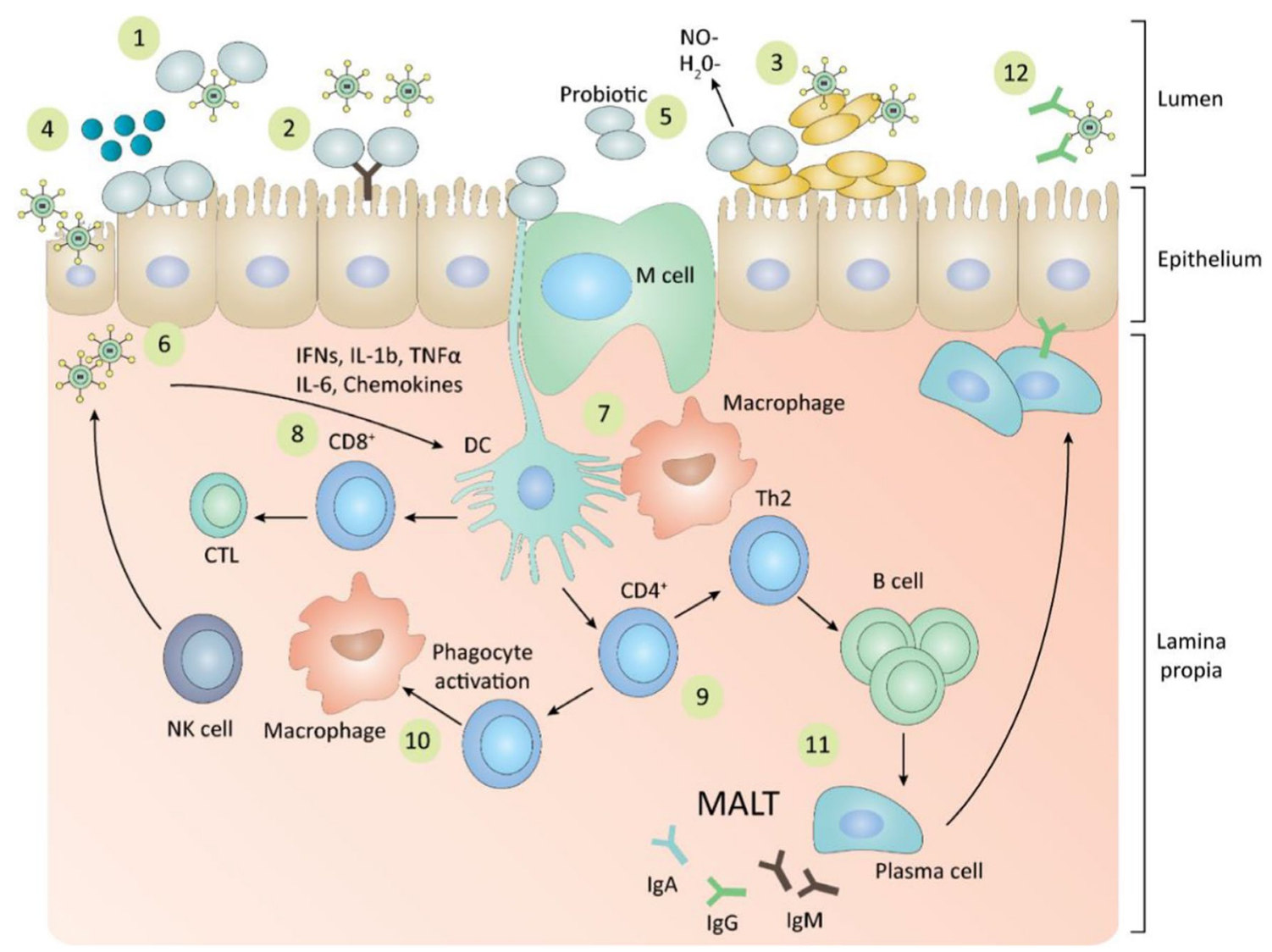

Fig. 1 The antiviral effects of probiotics during respiratory viral infections. MALT, mucosa-associated lymphoid tissue; NK cell, natural killer cell; CTL, cytotoxic T lymphocyte; Th1, T helper 1; Th2, T helper 2; DC, dendritic cell; M cell, microfold cell; IgM, immuno-

- Induction of mucosal protection (gut mucins may attach to viruses and restrain viral replication)

- Production of antiviral components such as bacteriocins and hydrogen peroxide $\left(\mathrm{H}_{2} \mathrm{O}_{2}\right)$

- Induction of low-level nitric oxide (NO) generation by host cells and dehydrogenase formation

- Immunomodulation of immune cells (such as macrophages and dendritic cells [DCs])

- Induction of the differentiation of $\mathrm{CD}^{+} \mathrm{T}$ cells into CTLs, which kill infected cells

- Differentiation of $\mathrm{CD} 4^{+} \mathrm{T}$ cells into Th1 and Th2 cells (and induction of B cells by Th2-cells) [84, 178].

\section{Clinical outcomes of using probiotics as a prophylactic approach for viral respiratory infections}

Lactobacillus and Bifidobacterium are two main genera that are commonly used as probiotics [52]. The beneficial effects of probiotics on viral infections have been reported globulin M; IgG, immunoglobulin G; IgA, immunoglobulin A; IFNs, interferons; IL-1b, interleukin 1 beta; TNF-a, tumour necrosis gactor alpha; IL-6, interleukin 6; NO, nitric oxide

[97, 178]. A list of probiotic bacteria administered in viral respiratory infections is shown in Table 1 . In this section, we describe some of the promising research findings (Table 2).

Luoto and colleagues studied early modifications of immune responses and gut microbiota following Lactobacillus rhamnosus $\mathrm{GG}$ administration to reduce the risk of viral respiratory infections in preterm newborns during their first year of life [113]. They found a significant reduction in the frequency of VRIs, in particular rhinovirus infections, when administering specific probiotic metabolites such as galactooligosaccharides and polydextrose. They also observed immunomodulatory effects that conferred clinical benefits exceeding those due to interference with viral growth [113]. The rationale for the administration of probiotics for the prevention of VRIs is based on their capacity to diminish colonization of respiratory epithelia by pathogens and control mucosal resistance via activation of inflammasomes and systemic immune reactions [55, 79]. It has been demonstrated that early treatment with dietary L. rhamnosus GG in preterm newborns can have long-lasting effects and decrease the risk of VRIs. In separate studies, Kumpu and colleagues 
Table 1 Clinical outcome of using probiotic bacterial strains for viral respiratory infections.

\begin{tabular}{lll}
\hline Bacterial strain & Viral respiratory infection & Outcome \\
\hline Lactobacillus GG (LGG) & Respiratory tract infections & $\begin{array}{l}\text { The study assessed the performance of } \\
\text { LGG in the restriction of respiratory tract } \\
\text { diseases in children attending daycare } \\
\text { centers. Their results indicated that LGG } \\
\text { treatment could be advised as a valid }\end{array}$ \\
& means of reducing the risk of upper \\
& respiratory tract diseases in children \\
& attending daycare centers.
\end{tabular}

Lactobacillus paracasei $\mathrm{N} 1115$

Haemophilus influenzae, Streptococcus, Corynebacterium, Moraxella, Staphylococcus aureus

Lactobacillus rhamnosus GG

Lactobacillus rhamnosus GG
Upper respiratory tract infections (URTI) The investigation was to evaluate whether

Respiratory syncytial virus (RSV)

Respiratory tract infections

Respiratory illness yogurt enriched with a probiotic strain could benefit middle-aged and older adults suffering from severe URTIs in a randomized, blank-controlled, parallelgroup trial. The study results recommended that yogurt with chosen probiotic strains such as N1115 may diminish the risk of severe upper tract diseases in the elderly. The augmentation of T-cellmediated immune protection might be one of the critical underlying mechanisms by which probiotics help to alleviate infections.

The study assessed whether specific nasopharyngeal microbiota are correlated with distinct host transcriptomic profiles and infection severity in children infected with RSV. The study results showed that the interplay between RSV and nasopharyngeal microbiota might temper host immune responses, possibly altering the clinical severity of the disease.

The study hypothesized that early prebiotic or probiotic supplementation could decrease the risk of virus-associated RTIs throughout the first year of life in a cohort study on preterm infants. The results demonstrated that altering gut microbiota with specific prebiotics and probiotics might represent a novel and cost-effective approach to decreasing the risk of rhinovirus infections.

Reference

This study showed that long-term daily use of milk containing Lactobacillus rhamnosus GG decreased the rate of respiratory illnesses in children attending daycare centers (those who finished the treatment course, and not the whole population). 
Table 1 (continued)

\begin{tabular}{ll}
\hline Bacterial strain & Viral respiratory infection \\
\hline Lactobacillus rhamnosus GG & Respiratory tract infection
\end{tabular}

Outcome

In this randomized, double-blinded,

Bifidobacterium lactis subs plactis B1-04 Lactobacillus acidophilus NCFM

Bifidobacterium animalis subsp. Lactis Bi-07

Lactobacillus gasseri PA 16/8, Bifidobacterium longum SP 07/3, B. bifidum MF 20/5 placebo-controlled 28-week intervention, nasopharyngeal swab specimens were obtained from children suffering from respiratory infections who were given normal milk $(\mathrm{N}=97)$ or the same milk enriched with the probiotic Lactobacillus rhamnosus $\mathrm{GG}(\mathrm{N}=97)$. This study showed that children taking Lactobacillus rhamnosus $G G$ had a shorter time with respiratory manifestations than children in the control group. However, probiotic treatment did not decrease the amount of viral shedding or the severity of respiratory signs.

This study examined the treatment and prevention performance of three commercial probiotic products on pediatric infectious diseases in a double-blind, randomized, controlled trial. This investigation showed that $L$. casei could alleviate bacterial, viral, and respiratory infections.
Respiratory tract infection

Common cold
This study aimed to examine the effect of supplementation with probiotics on respiratory and gastrointestinal disorders in healthy working men and women. This study indicated that the Bl-04 probiotic taken as a nutritional supplement was beneficial for decreasing the risk of URTI in healthy, physically active adults.

This study evaluated the effects of using $L$. gasseri PA 16/8, B. longum SP 07/3, and B. bifidum MF $20 / 5\left(5 \times 10^{7}\right) \mathrm{cfu} /$ tablet $)$ for at least three months on the severity of manifestations and the frequency and duration of the common cold. This study showed that the intake of probiotic bacteria for at least three months significantly decreased the duration by approximately two days and diminished the severity of manifestations.

The co-adjuvant capacity of the oral administration of the breast-milk-isolated strain Lactobacillus fermentum (CECT5716) with an anti-influenza vaccine was evaluated. This study demonstrated that oral treatment with $L$. fermentum CECT5716 potentiates the immunologic responses to the anti-influenza vaccine and may enhance protection by boosting the T-helper type 1 response and eliciting the virus-neutralizing antibodies. 
Table 1 (continued)

\begin{tabular}{|c|c|c|c|}
\hline Bacterial strain & Viral respiratory infection & Outcome & Reference \\
\hline Lactobacillus casei DN-114 001 & Respiratory tract infection & $\begin{array}{l}\text { The study investigated the ability of a } \\
\text { dairy product containing the probiotic } \\
\text { strain Lactobacillus casei DN-114 } 001 \\
\text { to protect independently-living elderly } \\
\text { individuals against widespread infectious } \\
\text { diseases. The results showed that the } \\
\text { consumption of the probiotic was cor- } \\
\text { related with a reduced duration of routine } \\
\text { infectious disorders, particularly URTIs } \\
\text { such as rhinopharyngitis, compared with } \\
\text { a control group. }\end{array}$ & {$[63]$} \\
\hline Lactobacillus bulgaricus OLL1073R-1 & Respiratory tract infection & $\begin{array}{l}\text { This study evaluated whether the con- } \\
\text { sumption of yogurt fermented with } \\
\text { Lactobacillus delbrueckii ssp. bul- } \\
\text { garicus OLL1073R-1 had a protective } \\
\text { effect against the common cold. The } \\
\text { results showed that the consumption of } \\
\text { yoghurt fermented with } L \text {. bulgaricus } \\
\text { OLL1073R-1 increased natural killer cell } \\
\text { activity and reduced the risk of catching a } \\
\text { common cold in the elderly. }\end{array}$ & [119] \\
\hline $\begin{array}{l}\text { Porphyromonas spp., } \\
\text { Granulicatella spp., } \\
\text { Fusobacterium spp., } \\
\text { Lachnospiraceae spp., } \\
\text { Haemophilus spp. }\end{array}$ & Influenza & $\begin{array}{l}\text { This study evaluated whether precise } \\
\text { bacterial community structures in the } \\
\text { nasopharynx of children during hospitali- } \\
\text { zation are correlated with various clinical } \\
\text { consequences of influenza. The results } \\
\text { showed that the expanded bacterial diver- } \\
\text { sity in the nasopharynx of children was } \\
\text { considerably correlated with influenza } \\
\text { severity. Patients with severe influenza } \\
\text { showed a reduced relative frequency } \\
\text { of S. aureus and increased abundance } \\
\text { of Prevotella, Streptobacillus, Porphy- } \\
\text { romonas, Granulicatella, Veillonella, } \\
\text { Fusobacterium, and Haemophilus in their } \\
\text { nasopharynx. This suggests the poten- } \\
\text { tial application of microbial signatures } \\
\text { as prognostic biomarkers of influenza } \\
\text { outcome. }\end{array}$ & [96] \\
\hline
\end{tabular}

surveyed the ability of L. rhamnosus GG to decrease the incidence and/or signs of viral infection in children [92]. They found that the duration of respiratory symptoms was notably shorter lower in children who received L. rhamnosus GG than in those who did not. However, in their study, $L$. rhamnosus GG treatment did not significantly decrease the incidence or symptoms of VRIs in the nasopharynx. This could be due to the comparably low dose of diurnal L. rhamnosus $\mathrm{GG}\left(10^{8} \mathrm{CFU}\right)$ administered in this trial compared with others [92].

Kumpu and colleagues identified several types of respiratory viruses in the nasopharynx of infants visiting daycare centers [92]. Hojsak and colleagues also investigated the ability of Lactobacillus GG to restrict gastrointestinal and respiratory tract infections (RTIs) in infants who visited daycare centers [75] and that the daily consumption of probiotics significantly decreased the incidence of upper RTIs.

In another study by Kumpu and colleagues, the effect of long-term daily consumption of milk containing L. rhamnosus GG was investigated on children with VRIs [91]. According to their results, a statistically significant reduction in respiratory manifestations was observed in the $L$. rhamnosus GG group compared to children in the placebo group. Lin and colleagues compared the efficacy of commercial probiotics on the incidence of VRIs in infants [110]. An exciting result of their work was that probiotic supplementation reduced the number of clinical visits, notably among those who had frequently been referred to physicians [110]. It concomitantly increased the number of infants who did not visit a physician during the interference phase, and the use of L. rhamnosus decreased VIs by $18 \%$ in the interference 


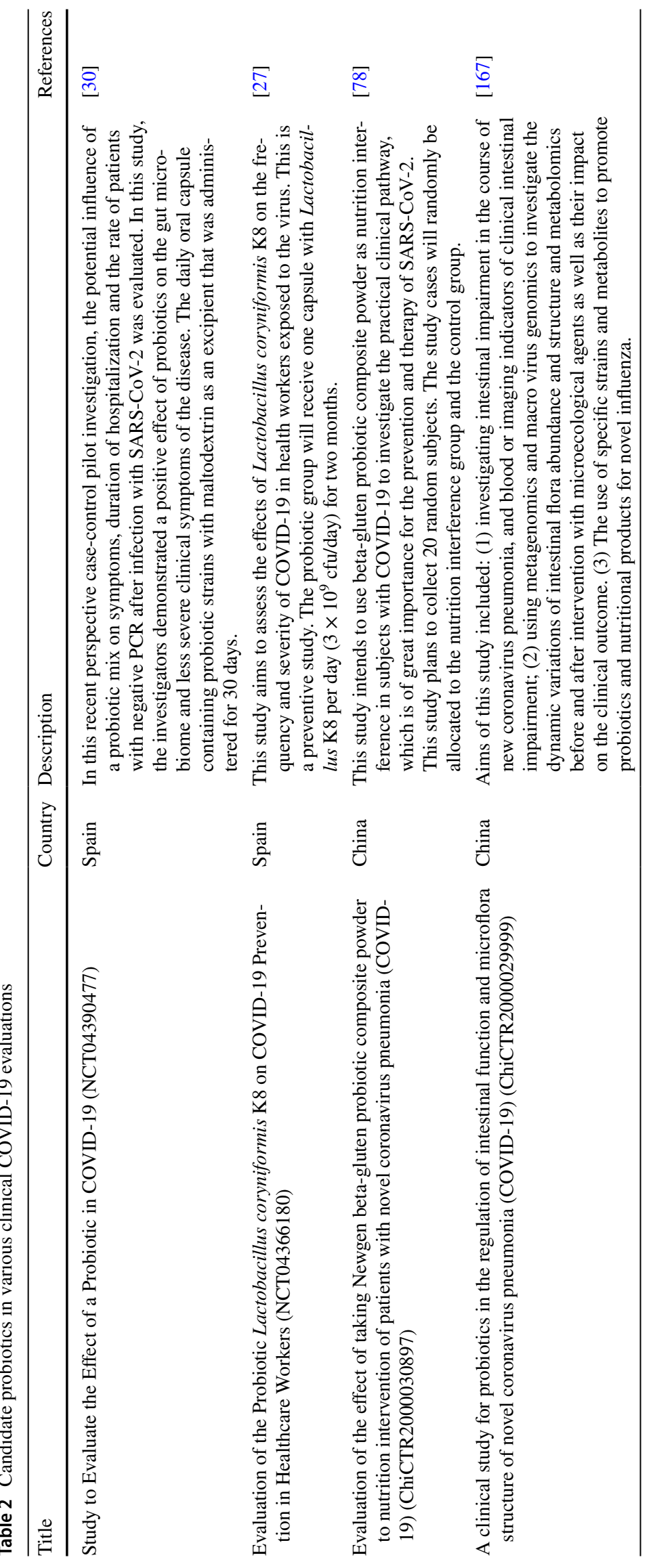




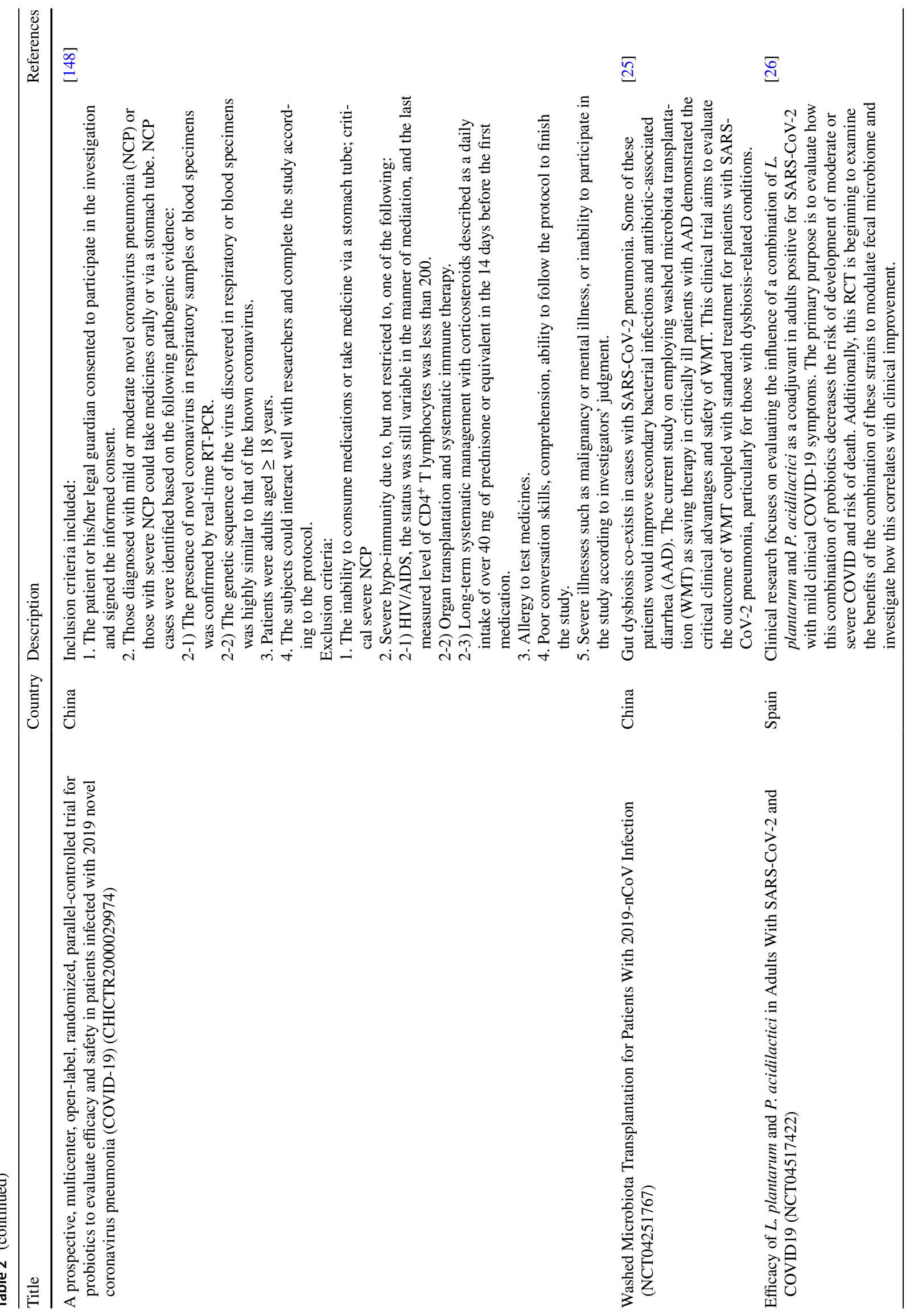


1828

R. Mirzaei et al.

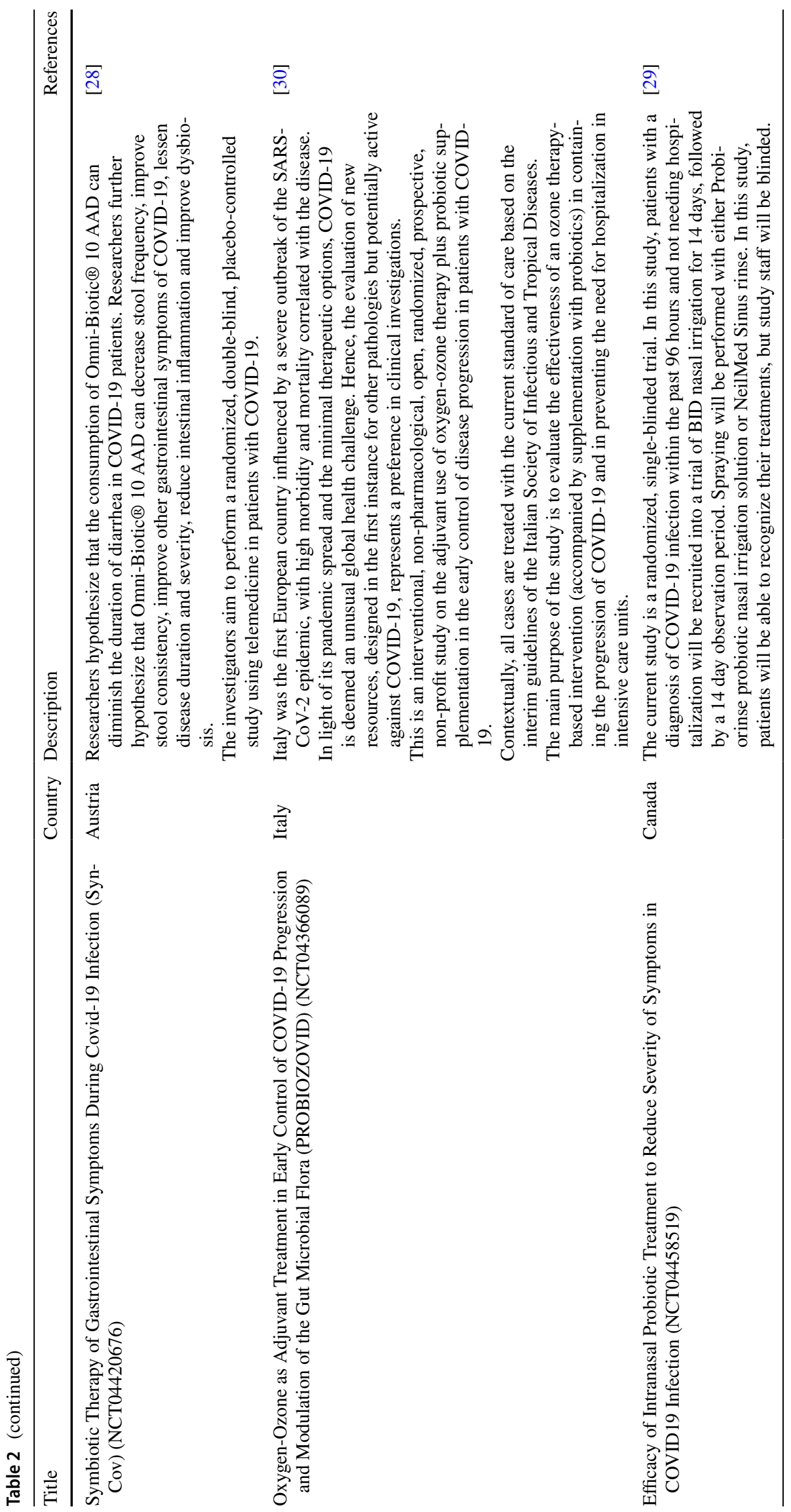

Springer 
group [110]. Probiotics, depending on the strain and species, can be potent modulators of the immune system [116, 117]. Lin and colleagues showed the effect of Lactobacillus spp. on antigen-specific IgG and cytokine reactions [110]. Specific Lactobacillus strains can induce myeloid DCs to activate $\mathrm{T}$ cells and induce the production of Th1 cytokines. They can therefore be considered potential biotherapeutic agents [130]. West and colleagues studied the effects of using a single strain, Bifidobacterium lactis subsp. lactis Bl-04, as a probiotic or a combination of Lactobacillus acidophilus NCFM and Bifidobacterium animalis subsp. lactis $\mathrm{Bi}-07$ on pulmonary and gastrointestinal diseases in healthy subjects [202]. They found that daily B. lactis Bl-04 supplementation led to a $27 \%$ decline in RTI incidence compared to a placebo. In seasonal infections similar to the common cold, a delay in disease incidence indicated an affirmative clinical advantage from supplementation.

Vrese and colleagues examined whether the consumption of probiotic bacteria for at least three months in winter/spring could affect the severity of signs, the frequency, and the duration of the common cold, as well as immune reactions in normal adults [39]. They showed that probiotic bacteria significantly decreased the average duration of infection and lessened the severity of symptoms [39]. These results were comparable to those of neuraminidase inhibitors (NIs), which, when used during the first $48 \mathrm{~h}$ of IV infection, decreased the severity of signs and decreased the infection duration by one day [39]. In contrast to NIs, probiotics can be administered as a part of the diurnal regimen and do not impose further costs. The reduced severity and duration of cold symptoms may be due to immunostimulatory effects, and in response to specific probiotic strains, distinct cell lines, such as peripheral blood mononuclear cells, monocytes, DCs, and intestinal cells from human mucosa have been shown to secrete pro- or anti-inflammatory cytokines and co-stimulatory molecules $[15,24,71]$. According to a study by Vrese and colleagues, CTLs, along with $\mathrm{CD} 8^{+} \mathrm{T}$ cells (suppressor cells), increased significantly throughout the initial 14 days of supplementation in a probiotic-treated group that was compared to control subjects [39].

Although vaccination against IVs is known to prevent severe illnesses, particularly in communities at risk, in some cases, vaccine efficacy is low, suggesting the need to develop new adjuvant components [122]. Some Lactobacillus strains (e.g., Lactobacillus fermentum CECT5716) have been suggested as suitable coadjuvants for increasing antibody production after IV vaccination [37]. During IV infection, innate immunity forms an early barrier against the virus via executive cells, molecules, and agents involved in the restriction of viral spread $[105,176]$. In this regard, Olivares and colleagues showed that oral administration of L. fermentum CECT5716 led to an increase in NK cells 14 days after vaccination [134]. Although IgA and IgG provide the crucial protective humoral immunity induced by IV infection, these authors observed an enhancement of the specific anti-IV IgA response in subjects receiving probiotics, but no such effect on IgG or IgM levels was observed [134].

Guillemard and colleagues investigated the beneficial effect of Lactobacillus casei DN-114 001 for protection of older adults against common RIs [64]. In their study, fermented products were shown to decrease the duration of common RIs. More importantly, significant reductions were observed for all RIs, in particular, rhinopharyngitis. In an unblinded trial, elderly individuals immunized against influenza and pneumococcus demonstrated a lower frequency of disease, particularly viral respiratory infections, after administration of a nutritional complement consisting of $L$. paracasei and additional nutrients such as vitamins [19]. The reduced duration of RIs could be correlated with a lowered risk of medical complications, because infections with human rhinoviruses, the most prevalent cause of RIs, were found to be correlated with a high incidence of prolonged disease and a lower rate of pulmonary disorders in older individuals [70, 188]. For instance, Guillemard and colleagues found that consumption of fermented dairy products containing $L$. casei DN-114 001 was linked to a significant reduction in the duration of common rhinopharyngitis, providing evidence that probiotics may have beneficial effects on RIs in the elderly [64].

Makino and colleagues assessed whether the consumption of yogurt fermented with Lactobacillus bulgaricus OLL1073R-1 improves immunity against RTIs such as the common cold and IV infections [119]. Their results showed that L. bulgaricus OLL1073R-1 significantly diminished the risk of common cold among the elderly. It was previously reported that 1073R-1 yogurt and its polysaccharides intensify NK cell activity in mice [118]. NK cells are involved in antiviral defense, and low NK cell activity has been linked to the development of common cold, pneumonia, acute bronchitis, and death in older adults [62, 133]. Hence, the effect of 1073R-1 yogurt is mainly associated with the immunostimulatory effect of polysaccharides formed by $L$. bulgaricus OLL1073R-1.

\section{Potential role of commensal microbiota in protecting the respiratory tract against infectious agents}

A notable difference in lung microbiota composition has been observed between SARS-CoV-2 pneumonia patients and healthy subjects, suggesting the occurrence of dysbiosis in the lung microbiota of COVID-19 patients [46]. Streptococcus salivarius is a prevailing commensal bacterium in the healthy oral and upper respiratory tract [46]. There have been several reports on interference by this bacterium with 
the growth of potential pathogens [46]. Along with other oral commensals, $S$. salivarius is commonly found in the lung and is associated with maintenance of good health [46]. The lung microbiota of COVID-19 patients is significantly modified and enriched in potentially pathogenic bacteria [46]. Strain K12 is the best-studied strain of S. salivarius [46]. Establishment of an upper respiratory tract (URT) infection with strain K12 can significantly decrease the occurrence of many viral URT infections, both in children and in older adults, possibly owing to its ability to induce IFN- $\gamma$ release and activate NK cells without triggering destructive inflammatory responses [16]. Although its efficacy against COVID-19 has never been investigated explicitly, its clinical potential as well as its safety profile, which can last $>20$ years following probiotic application, might encourage medical doctors to reconsider prescribing it as a supplement to help control viral respiratory infections and associated pneumonia by enhancing host immune functions.

Probiotic bacteria can inhibit colonization and establishment of infection by viral and bacterial pathogens [22]. For example, proteases generated by Staphylococcus epidermidis can degrade the biofilm structure of Staphylococcus aureus [82, 123, 152, 187]. In this regard, nasal administration of a bacterium that belongs to the healthy human microbiota benefits the patient by re-establishing a microbial balance and reducing the level of various pathogens in the airways [89].

IFN- $\lambda$ is a significant immune regulator in various VIs in the epithelial layer (mucosa), and stimulation of IFN- $\lambda$ production results in a quick response of immune cells to human respiratory viruses $[53,86]$. IFN- $\lambda$ is thought to be involved in the initial defense against viral attackers in the host respiratory system and plays a crucial role in local antiviral innate immunity $[53,86]$. Nevertheless, our current knowledge about the modulators that contribute to the production of IFN- $\lambda$, particularly in natural RVIs, is limited. The human mucosal surface is exposed to elements of the external environment and is thus sensitive to colonization and invasion by numerous pathogens [47]. Mucosal immunity appears to have evolved to accommodate the interaction between the host and the mucosal microbiome, with protection mediated by the microbiome against infections from outside microbial pathogens [74]. Various inhaled microbial pathogens encounter immune cells soon after their first contact with respiratory mucosa, and the microbial community in the nasal passage affects the primary immune reactions directly [87]. Understanding the microbiome of human nasal mucosa could provide substantial knowledge about the susceptibility of the respiratory tract to viral infections and components involved in immune reactions, such as IFNs. In a study on the regulation of the homeostasis of the human immune system by its microbiome, Kim and colleagues evaluated the microbial composition of healthy nasal mucosa [87]. They subsequently evaluated whether nasal commensal microbes are involved in signaling as part of the defense mechanism against IVA [87]. They identified S. epidermidis as the most frequent microbial population. They found that S. epidermidis cells collected from nasal mucosa of healthy subjects accelerated the elimination of IVA from the nasal epithelium via immune responses mediated by IFN- $\lambda$ [87]. In addition, nasal $S$. epidermidis cells from humans prevented IVA infection in mice by promoting innate immune reactions mediated by IFN $-\lambda$ in the nasal mucosa [87]. There have been reports of a crucial mechanistic association between susceptibility to various VIs and innate nasal immunity mediated by the microbiome.

Compositional and structural variations in the host respiratory microbiota arising from various environmental factors have been predicted, and the host respiratory microbiome has been found to be important for immune protection $[10,151]$. Therefore, an understanding of the composition of the respiratory mucosal microbiome and the substantial adverse effects of medications on these microbial communities is needed to develop novel methods for treating and preventing RIs. Nasal mucosa cells are crucial players in immunological resistance to infections of the respiratory system. They are responsible for the filtration of various respiratory microbial pathogens from normal inhalation to pressurized airflow. Various RVs confront host immunity primarily in the lower and upper respiratory epithelia [67, 81]. Protection against various viral infections can be attributed to the innate immune mechanisms of the human nasal epithelium for counteracting invasions by respiratory viruses [87]. Therefore, researchers must focus on the involvement of nasal microbiota, particularly S. epidermidis strains, in mucosal innate immune defense strategies against viruses. In the respiratory tract, innate immunity contributes to antiviral immunity through secretion of IFNs [139, 144]. The activity of type 1 IFNs in the stimulation of antiviral innate and adaptive immune reactions has been studied extensively $[136,198]$. IFN- $\lambda$ is an important factor in antiviral reactions against influenza viruses and rhinoviruses in human lungs [87]. It is also the prevailing IFN stimulated by IVA and is involved in the primary defense barrier against VIs in nasal epithelial cells [87]. Studies have focused on studying the host immune moderators involved in the production of IFN- $\lambda$ cytokines in the nasal mucosal layer, suggesting that the nasal microbiota may control IFN- $\lambda$ production [87]. Kim and colleagues demonstrated that $S$. epidermidis has potent antiviral activity in the nasal epithelium and that all antiviral reactions induced by this organism are mediated by IFN- $\lambda$, and not IFN- $\gamma$, IFN- $\beta$, or IFN- $\alpha$ [87].

Recent data have shown that commensal S. epidermidis can be sensed by Toll-like receptor 2 in the host nasal epithelium. However, IFN- $\lambda$ stimulated by $S$. epidermidis via signal transduction (ST) is associated with transcription factors (TFs). IFN regulatory factor 3 (IRF3) and IFN 
regulatory factor 7 (IRF7) are TFs that are associated with IFN- $\lambda$ and IFN production by direct ST via the phosphorylation of IRF7 and IRF3 [32, 217]. While IRF3 is usually thought to be required for triggering of IFN transcription, a deficiency in IRF3 has been shown to have little effect on the expression of IFN [32]. In contrast, the absence of IRF7 significantly reduces IFN production in the host airway epithelium [32]. Kim and colleagues showed that S. epidermidis cells as nasal commensals can increase the phosphorylation of IRF7 relative to IRF3 and eventually stimulate immune responses related to IFN- $\lambda$ in the host nasal epithelium [87]. However, they did not determine the molecular mechanism that prompted phosphorylation of IRF7 by $S$. epidermidis. It can be speculated that free molecules from $S$. epidermidis interact with IRF7 and prompt strong IFN-related antiviral immune reactions in the airways. Comparative genomic studies can explain how innate immunity reactions are stimulated to react with symbiotic commensals. These findings provide further information about how the nasal commensals enhance IFN-dependent innate immunity against IVA infections to protect the respiratory tract. These findings indicate that, as the prevailing nasal commensal in humans, S. epidermidis improves protection against IVA infection in nasal epithelium via IRF-7-dependent production of IFN- $\lambda$ and prevents IVA lung infection via the suppression of IVA replication in nasal mucosa. Therefore, intranasal inoculation with S. epidermidis might be an effective way of preventing viral respiratory infections through the stimulation of IFN$\lambda$-related innate immune reactions.

Most importantly, in a promising approach, researchers from Stanford University have started a clinical trial to investigate whether IFN- $\lambda$-treatment can help COVID-19 patients and decrease transmission of virus, since IFN- $\lambda$ appears to help control viral respiratory diseases such as influenza and SARS [121].

\section{Dysbiosis of gut microbiota in COVID-19 patients}

Dysbiosis, which is defined as a persistent imbalance of the microbiota, has been associated with several intestinal and extraintestinal diseases [11]. Studies have indicated an association between the pharyngeal microbiota and SARSCoV-2 infection [18]. According to these studies, the composition of the pharyngeal microbiota change with age, with older individuals having a less diverse microbial community [5]. This might contribute to the higher susceptibility of the aged to COVID-19, but more investigations are needed to confirm this. Dysbiosis can lead to an inflammatory milieu that can be exploited by SARS-CoV-2 [5]. It has been found that cytokines are elevated following COVID-9, possibly leading to a "cytokine storm," which can be more harmful than the virus itself $[5,209]$. Recent studies have recognized bacterial markers associated with sensitivity to SARSCoV-2 infection [59]. Based on the data from COVID-19 subjects, a blood proteomic risk score (PRS) was designed to predict the progression and severity of SARS-CoV-2 disease [59]. It was found that Ruminococcus gnavus had a positive correlation with inflammation, while Clostridia spp. showed a negative correlation [59]. A strong association was also demonstrated between the severity of SARS-CoV-2 infection in the elderly and the bacteria mentioned above as well as the PRS. This study investigated a subgroup of 301 healthy individuals over three years [59]. Interestingly, microbiome modifications were indicated by the PRS, implying that dysbiosis stimulated protein modifications [59].

The SARS-CoV-2 S glycoprotein binds to human ACE2 [205], an enzyme that is expressed in esophageal and intestinal epithelia as well as lung tissue, and this could contribute to dysbiosis in the normal flora and gastrointestinal symptoms following SARS-CoV-2 infection [61, 76, 102]. Moreover, SARS-CoV-2 and its genetic material have been identified in the faeces of patients with diarrhea [95, 216, $218]$ indicating the presence of SARS-CoV-2 in the human gastrointestinal tract and its possible transmission by the fecal-oral route.

\section{The potential effects of probiotics on coronavirus infections and COVID-19}

Many studies are being undertaken to investigate the effects of probiotics on several coronavirus strains, as they are safe and capable of modulating immune reactions [83, 131]. In addition, a clinical study has described an imbalance in intestinal microbiota and significantly reduced levels of probiotics such as Lactobacillus and Bifidobacterium in COVID-19 cases, possibly facilitating secondary bacterial infections [206]. A recent study has demonstrated that porcine epidemic diarrhea virus (PEDV) can be inhibited using cell-free supernatants or live lactic acid bacteria [171]. In that study, using CPE reduction assays and qualitative immunofluorescence, it was shown that probiotics could be useful in eliminating PEDV in a strain-specific manner [171]. In a different study, Lactobacillus casei was employed as a vehicle for the DC-targeting peptide (DC-pep) along with the PEDV core neutralizing epitope (COE) antigen [196]. It was shown that a genetically modified Lactobacillus casei oral vaccine could induce the production of $\operatorname{IgG}$ (systemic) and SIgA antibody (mucosal) in a murine model [196]. Several other studies have employed various probiotics to present PEDV genes or antigens of interest [111, 114, 196, 197]. Liu et al. [111] showed that an altered Lactobacillus plantarum 
strain had antiviral activity against coronavirus infections in a porcine intestinal epithelial cell line.

The sequencing of microbiota in COVID-19 patients has shown a significant decrease in bifidobacteria and lactobacilli as the prevailing symbiotic bacteria and an increase in the number of opportunistic bacteria such as Corynebacterium or Ruthenibacterium [51]. The immune system in the lung can be affected by intestinal dysbiosis, which therefore might aggravate respiratory distresses caused by COVID-19 [23]. In this regard, oral bacteriotherapy might be useful. Some strains of the genera Lactobacilli and Bifidobacterium have a protective function against IV, RVs, RSV, adenovirus, and pneumovirus [20,115]. As no definitive treatments or guidelines have been established for COVID-19, d'Ettorre et al. [33] investigated the efficacy of oral bacteriotherapy as an additional curative option to prevent the progress of COVID-19. Their bacterial formulation included Streptococcus thermophilus DSM 32345, L. acidophilus DSM 32241, Lactobacillus helveticus DSM 32242, Lactobacillus paracasei DSM 32243, Lactobacillus Plantarum DSM 32244, Lactobacillus brevis DSM 27961, Bifidobacterium lactis DSM 32246, Bifidobacterium lactis DSM 32247 [33]. They investigated two groups: 1) patients treated with hydroxychloroquine, tocilizumab, and antimicrobials alone or in combination and 2) patients treated with oral bacteriotherapy plus a conventional medication regimen [33]. Their results showed that patients who also received bacteriotherapy had a higher survival rate and a lower need for intensive resuscitation [33]. The predicted risk of developing respiratory collapse due to COVID-19 infection was lower in patients who received oral bacteriotherapy [33]. When other manifestations of COVID-19 were considered, including asthenia, pyrexia, cough, dyspnea, diarrhea, and myalgia, a notable improvement was already seen as early as $24-48 \mathrm{~h}$ after the start of the bacteriotherapy [33]. The authors hypothesized that in COVID-19 patients, bacterial compounds with the "proper" immunological and biochemical profiles could promote host immunity. The antioxidant pathway nuclear factor erythroid 2p45-related factor 2 (Nrf2) and heme oxygenase-1 (HO-1) were elevated in response to the bacterial formulation [21]. These molecules can modulate oxidative stress, thereby exerting antiviral functions [33]. Antiviral activity of Nrf2 and HO-1 has been observed against human immunodeficiency virus (HIV), IV, RSV, Ebola virus, and dengue virus $[45,48,69,72,182]$. Interestingly, the beneficial characteristics of $\mathrm{HO}-1$ include activity against respiratory viruses.

COVID-19 is a severe pulmonary disease, with manifestations including fever, cough, breathing difficulty, fatigue, muscle pain, diarrhea, sore throat, and abdominal disorders $[137,170]$. While most patients experience mild symptoms, some experience viral pneumonia and multiple organ failure [211]. Until now, COVID-19 prevention has been based on maintaining good hygiene by washing hands and avoiding contact with infected individuals [138], but reinforcing the immune system might also be helpful (Fig. 2) [173]. In the human body, trillions of beneficial bacteria live in homeostasis to help their host to digest food, produce precursors for neurotransmitters, and enhance the immune response against pathogens [12]. It has been found that microbiota dysbiosis is associated with several disorders [42]. Probiotic bacteria can interact with microbiota to reinforce the immune system and prompt immune reactions [203, 208]. Some probiotics have been found to prevent bacterial and viral infections or decrease their duration. Lactobacillus reuteri DSM 17938 has been shown to be protective against RI signs and gastrointestinal disorders such as diarrhea in children $[2,65$, 200]. It has also been found that probiotics can be useful in enhancing vaccine immunogenicity, increasing the rate of seroconversion and seroprotection in adults immunized with flu vaccines [99]. Additionally, probiotics, together with vitamins, can enhance the immune system. For example, vitamin D can modulate immune reactions [7].

Although its pathophysiological mechanism has not been entirely elucidated, COVID-19 is known to affect the lungs and airways [210]. However, since immunological mechanisms play an important role in the course of the disease, a novel therapeutic approach involving probiotic bacterial strains might be promising because of their involvement in immune modulation $[120,204,210]$. In this regard, interleukin-17 is a pro-inflammatory cytokine with a crucial role in the adaptive immune system, and it is also a potent inducer of endoplasmic reticulum stress autophagy through inositol-requiring enzyme $1[17,88]$. By blocking this interleukin, autophagy mediated by endoplasmic reticulum stress and inflammation can be prevented [60,88]. Interestingly, Bifidobacterium strains have an inhibitory effect on interleukin-17 [17]. Consequently, administration of high doses of Bifidobacterium strains such as B. animalis subsp. lacti BB-12 as well as lipopolysaccharides from this strain [164, 174] could be used as a therapeutic and preventive approach in COVID-19 patients, particularly in those with gastrointestinal symptoms.

A biotechnology company (Biosearch Life) found that Lactobacillus coryniformis CECT5711 K8 can decrease virus transmission during respiratory infections in older adults. Accordingly, they assessed the efficacy of K8 in diminishing the frequency or severity of SARS-CoV-2 in a clinical trial [80]. In a study by Xu et al. [207], some COVID-19 patients develop intestinal microbial dysbiosis with lowered levels of probiotics such as Bifidobacterium and Lactobacillus. Therefore, gastrointestinal health should be assessed in all COVID-19 patients. The application of probiotics and nutritional support has been shown to maintain intestinal microbiota equilibrium and decrease the hazard of secondary bacterial infections [207]. Recent work by 


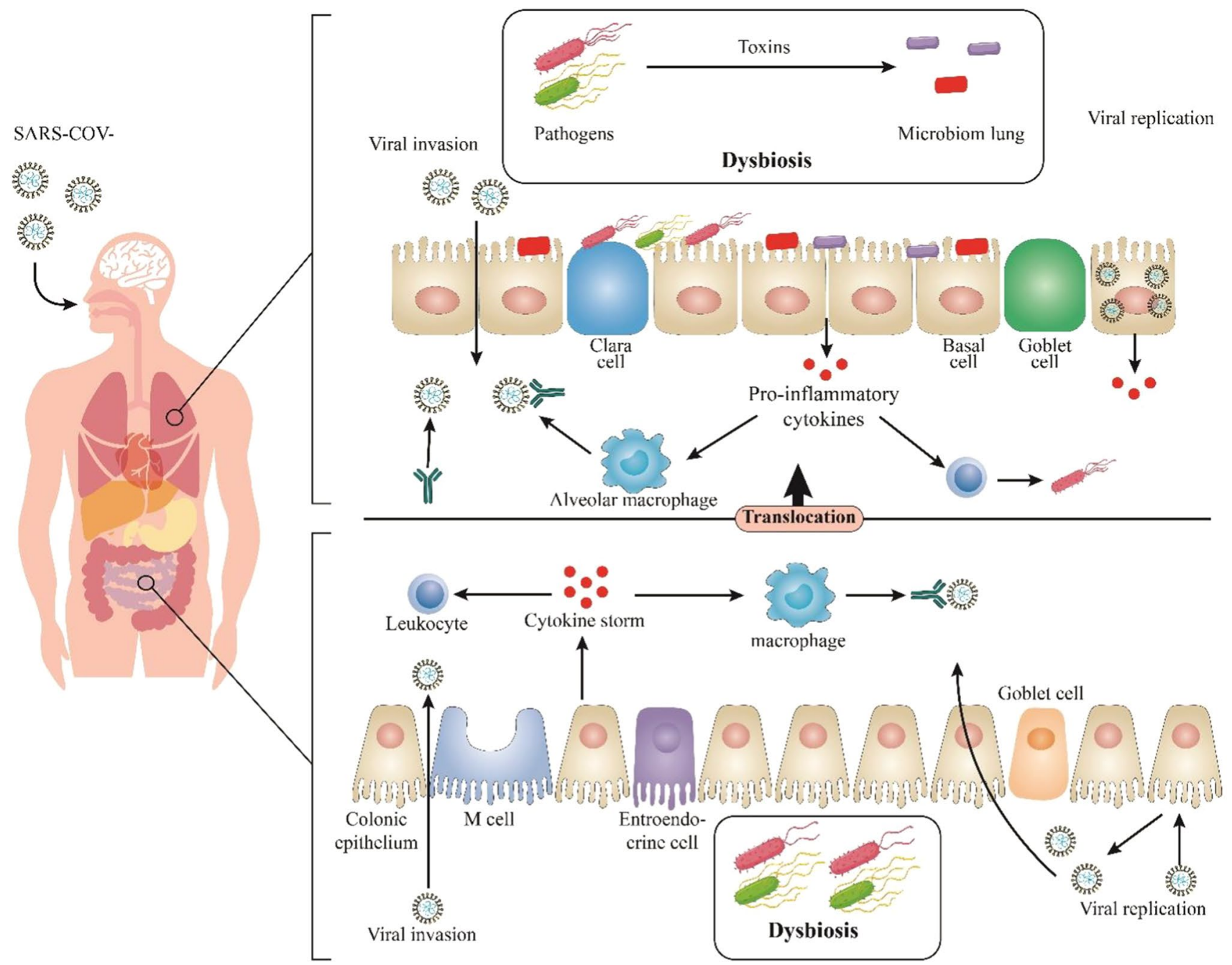

Fig. 2 The antiviral effects of probiotics during SARS-CoV-2 infection

Yoon et al. showed that Lactobacillus gasseri could decrease the spread of SARS-CoV-2 by inhibiting purine as the viral energy source, as this source is required for mutation of the virus; hence, it can be expected that probiotic bacteria can be considered as potent supplements to suppress the spread of COVID-19 by inhibiting purine activity [157]. However, the reinforcement of immune reactions by safe strategies, such as maintaining a normal gut microbial heterogeneity and preventing colonic dysbiosis in the aged, children, and the general community, is probably beneficial for recovery from COVID-19. A balanced diet with probiotics and vitamin supplementation can help to reinforce the immune system against SARS-CoV-2.

Several metabolites derived from Lactobacillus plantarum, including plantaricin, lactic acid, acetic acid, and gamma-aminobutyric acid, can boost the immune response against viral pathogens [4]. In order to initiate infection, the virus must recognize its receptor. Lie et al. [103] suggested that the binding affinity of SARS-CoV-2 for hACE2 is linked to the rate of viral transmission and the severity of disease. SARS-CoV-2 enters host cells through $\mathrm{S}$ glycoprotein homotrimers on the viral surface $[181,191]$. The S glycoprotein binds human ACE2 receptors with high affinity [189]. Anwar et al. [6] targeted both the S glycoprotein and ACE2 using a plantaricin metabolite and showed that plantaricin, via binding to the receptor binding domain (RBD), prevents the entry of SARS-CoV-2. They also targeted the viral RNAdependent RNA polymerase (RdRp), which is required for viral replication. Anwar et al. [6] chose four metabolites produced by Lactobacillus plantarum (metabolites derived from plantaricin, including plantaricin BN, plantaricin JLA9 , plantaricin $\mathrm{W}$, and plantaricin $\mathrm{D}$ ) to design antiviral drugs that, based on computer simulations, showed the potential to be employed as probiotics to delay, prevent, and eliminate SARS-CoV-2 in individuals by hindrance or inactivation of $\mathrm{RdRp}$, prevention of the emergence of newly budded virus 
progeny, inhibition of the RBD fragment of the S protein, or interference with other proteins such as the ACE2 receptor. They used computational analysis to predict the antiviral activity of plantaricin compounds through several different mechanisms. Metabolic products of Lactobacillus plantarum inhibit viral entry by interacting with RdRp, RBD, and ACE2 [1, 6]. Blocking the S protein, a major structural protein with a pivotal function in the life cycle of SARSCoV-2, could be one of the most promising strategies [6]. This was confirmed by a molecular model that established the durability of the networks of plantaricin $w$ and SARSCoV-2 (RdRp, RBD, and ACE2 receptor) [6]. Computational and molecular models can accurately identify drugs that can be repurposed without requiring clinical trials. Moreover, it would be challenging to discover a medication that has a more favorable protection profile or a lower cost than macrolides. The use of plantaricin metabolites under proper medical supervision should be considered as a temporary measure until a definite antiviral drug is discovered for COVID-19.

\section{A promising probiotic-based oral candidate vaccine against SARS-CoV-2}

Several vaccines have been developed against SARS-CoV-2, and others are undergoing clinical trials [54, 192, 213]. Injected vaccines are costly and require expert administration, whereas, oral vaccines are more affordable, simple to store, easy to administer, and bio-friendly $[94,162,166]$. It has also been shown that oral vaccines can induce the robust production of specific $\operatorname{IgG}$ and $\operatorname{IgA}$ as well asTh1 and Th17 responses, thereby inhibiting viral replication in the respiratory tract and intestinal mucosa [109, 132, 195]. Thus, an efficient oral vaccine for SARS-CoV-2 would be of great benefit.

Lactic acid bacteria are potentially suitable bacterial vectors for oral DNA and protein delivery. They are frequently present in the human intestine and are beneficial in several gastro-intestinal and inflammatory diseases $[43,77,159$, $163,168,172]$. L. plantarum is generally known as a probiotic that can be employed in food, vaccines, and medication [9, 112, 153-156, 165]. Therefore, Wang et al. [194] developed an L. plantarum expression system for SARS-CoV-2 $\mathrm{S}$ protein production. By optimizing the codon usage of the $\mathrm{S}$ gene, the $\mathrm{S}$ protein was efficiently presented on the bacterial surface, leading to the generation of many misfolded peptide chains. This protein showed strong reactivity with an anti-HA-tagged rabbit polyclonal antibody and SARSCov-2-S-protein-specific monoclonal antibodies [194]. The stability of the immunogenic protein is crucial for oral vaccines. Therefore, they examined the stability of the S protein presented on the bacterial surface and found that it was resistant to heat and low $\mathrm{pH}$. The expression level of this protein was elevated following exposure to $0.2 \%$ bile salt, implying that the recombinant form of $L$. plantarum $\mathrm{Lp} 18: \mathrm{S}$ could be applied as an oral vaccine for COVID-19 [194].

\section{Conclusion}

SARS-CoV-2 is a newly emerging pathogen, and researchers are still in the early stage of understanding how this virus acts and the mechanisms by which it induces an immune response. Although the advantages of drugs and vaccines for the treatment and prevention of VIs have been demonstrated, their efficiency can be limited by changes that occur in viral populations, making it challenging to apply an entirely practical approach to prevent viral infections. However, the administration of probiotics can be beneficial in preventing VRIs, including COVID-19, and probiotic therapy may be considered as an alternative for the amelioration and/or prevention of COVID-19 disease. Overall, the application of probiotic bacteria against COVID-19 appears to be promising, both in terms of vaccination and treatment.

Author contributions RM, AT, SP, EJ, SRHF, ASJ, SK, SA, PM, SJ, and RYM participated in the study design, wrote the draft, and collected the documentation materials. MAH, HK, and SK participated in the study design and helped revise the draft. All authors read and approved the manuscript.

\section{Compliance with Ethical Standards}

Conflict of interest The authors declare that they have no conflicts of interest.

\section{References}

1. Aanouz I, Belhassan A, El-Khatabi K, Lakhlifi T, El-Ldrissi M, Bouachrine M (2020) Moroccan medicinal plants as inhibitors against SARS-CoV-2 main protease: computational investigations. J Biomol Struct Dyn. https://doi.org/10.1080/07391102. 2020.1758790

2. Agustina R, Kok FJ, Van De Rest O, Fahmida U, Firmansyah A, Lukito W, Feskens EJ, Van Den Heuvel EG, Albers R, BoveeOudenhoven IM (2012) Randomized trial of probiotics and calcium on diarrhea and respiratory tract infections in Indonesian children. Pediatrics 129:e1155-e1164

3. Al Kassaa I (2016) Antiviral probiotics: a new concept in medical sciences. New Insights Antiviral Probiotics:1-46

4. Albarracin L, Kobayashi H, Iida H, Sato N, Nochi T, Aso H, Salva S, Alvarez S, Kitazawa H, Villena J (2017) Transcriptomic analysis of the innate antiviral immune response in porcine intestinal epithelial cells: influence of immunobiotic lactobacilli. Front Immunol 8:57

5. Antunes AE, Vinderola G, Xavier-Santos D, Sivieri K (2020) Potential contribution of beneficial microbes to face the COVID19 pandemic. Food Res Int 136:109577 
6. Anwar F, Altayb HN, Al-Abbasi FA, Al-Malki AL, Kamal MA, Kumar V (2020) Antiviral effects of probiotic metabolites on COVID-19. J Biomol Struct Dyn. https://doi.org/10.1080/ 07391102.2020.1775123

7. Aranow C (2011) Vitamin D and the immune system. J Investig Med 59:881-886

8. Atkinson SK, Sadofsky LR, Morice AH (2016) How does rhinovirus cause the common cold cough? BMJ Open Respir Res 3:e000118-e000118

9. Bae J-h, Kim MS, Kim H, Dal Kang S, Shim S, Lee D, Seo J-h, Kang H, Han NS (2019) Suitability of lactobacillus plantarum SPC-SNU 72-2 as a probiotic starter for sourdough fermentation. J Microbiol Biotechnol 29:1729-1738

10. Bassis CM, Tang AL, Young VB, Pynnonen MA (2014) The nasal cavity microbiota of healthy adults. Microbiome 2:27

11. Belizário JE, Faintuch J (2018) Microbiome and gut dysbiosis Metabolic Interaction in Infection. Springer, Berlin, pp 459-476

12. Belkaid Y, Hand TW (2014) Role of the microbiota in immunity and inflammation. Cell 157:121-141

13. Boge T, Rémigy M, Vaudaine S, Tanguy J, Bourdet-Sicard R, Van Der Werf S (2009) A probiotic fermented dairy drink improves antibody response to influenza vaccination in the elderly in two randomised controlled trials. Vaccine 27:5677-5684

14. Boncristiani HF, Criado MF, Arruda E (2009) Respiratory viruses. Encyclopedia Microbiol. https://doi.org/10.1016/B978012373944-5.00314-X

15. Borruel N, Casellas F, Antolın M, Llopis M, Carol M, Espiin E, Naval J, Guarner F, Malagelada JR (2003) Effects of nonpathogenic bacteria on cytokine secretion by human intestinal mucosa. Am J Gastroenterol 98:865-870

16. Bouwer AL, Saunderson SC, Dunn AC, Lester KL, Crowley LR, Jack RW, McLellan AD (2013) Rapid interferon-gamma release from natural killer cells induced by a streptococcal commensal. J Interferon Cytokine Res 33:459-466

17. Bozkurt HS, Quigley EM (2020) The probiotic Bifidobacterium in the management of Coronavirus: a theoretical basis. Int $\mathbf{J}$ Immunopathol Pharmacol. https://doi.org/10.1177/2058738420 961304

18. Budding A, Sieswerda E, Wintermans B, Bos M (2020) An age dependent pharyngeal microbiota signature associated with SARS-CoV-2 infection. Available at SSRN 3582780

19. Bunout D, Barrera G, Hirsch S, Gattas V, de la Maza MP, Haschke F, Steenhout P, Klassen P, Hager C, Avendaño M (2004) Effects of a nutritional supplement on the immune response and cytokine production in free-living Chilean elderly. J Parenter Enter Nutr 28:348-354

20. Canani RB, Di Costanzo M, Leone L, Pedata M, Meli R, Calignano A (2011) Potential beneficial effects of butyrate in intestinal and extraintestinal diseases. World J Gastroenterol 17:1519

21. Castelli V, d'Angelo M, Lombardi F, Alfonsetti M, Antonosante A, Catanesi M, Benedetti E, Palumbo P, Cifone MG, Giordano A (2020) Effects of the probiotic formulation SLAB51 in in vitro and in vivo Parkinson's disease models. Aging (Albany NY) $12: 4641$

22. Chiu L, Bazin T, Truchetet M-E, Schaeverbeke T, Delhaes L, Pradeu T (2017) Protective microbiota: from localized to longreaching co-immunity. Front Immunol 8

23. Chiu L, Bazin T, Truchetet M-E, Schaeverbeke T, Delhaes L, Pradeu T (2017) Protective microbiota: from localized to longreaching co-immunity. Front Immunol 8:1678

24. Christensen HR, Frøkiær H, Pestka JJ (2002) Lactobacilli differentially modulate expression of cytokines and maturation surface markers in murine dendritic cells. J Immunol 168:171-178
25. ClinicalTrials.gov (2020) Washed Microbiota Transplantation for Patients With 2019-nCoV Infection.

26. ClinicalTrials.gov (2020) Efficacy of L. Plantarum and P. Acidilactici in Adults With SARS-CoV-2 and COVID19.

27. ClinicalTrials.gov (2020) Evaluation of the Probiotic Lactobacillus Coryniformis K8 on COVID-19 Prevention in Healthcare Workers.

28. ClinicalTrials.gov (2020) Synbiotic Therapy of Gastrointestinal Symptoms During Covid-19 Infection (SynCov).

29. ClinicalTrials.gov (2020) Efficacy of Intranasal Probiotic Treatment to Reduce Severity of Symptoms in COVID19 Infection.

30. ClinicalTrials.gov (2020) Oxygen-Ozone as Adjuvant Treatment in Early Control of COVID-19 Progression and Modulation of the Gut Microbial Flora (PROBIOZOVID).

31. Cotton M, Innes S, Jaspan H, Madide A (2004) Rabie H (2008) Management of upper respiratory tract infections in children. S Afr Fam Pract 50:6-12

32. Crotta S, Davidson S, Mahlakoiv T, Desmet CJ, Buckwalter MR, Albert ML, Staeheli P, Wack A (2013) Type I and type III interferons drive redundant amplification loops to induce a transcriptional signature in influenza-infected airway epithelia. PLoS Pathog 9:e1003773

33. d'Ettorre G, Ceccarelli G, Marazzato M, Campagna G, Pinacchio C, Alessandri F, Ruberto F, Rossi G, Celani L, Scagnolari C (2020) Challenges in the management of SARS-CoV2 infection: the role of oral bacteriotherapy as complementary therapeutic strategy to avoid the progression of COVID-19. Front Med 7:389

34. Dasaraju PV, Liu C (1996) Chapter 93: infections of the respiratory system. Medical microbiology 4th ed Galveston: University of Texas Medical Branch at Galveston

35. Dawood FS, Iuliano AD, Reed C, Meltzer MI, Shay DK, Cheng P-Y, Bandaranayake D, Breiman RF, Brooks WA, Buchy P (2012) Estimated global mortality associated with the first 12 months of 2009 pandemic influenza A H1N1 virus circulation: a modelling study. Lancet Infect Dis 12:687-695

36. de Steenhuijsen Piters WA, Heinonen S, Hasrat R, Bunsow E, Smith B, Suarez-Arrabal M-C, Chaussabel D, Cohen DM, Sanders EA, Ramilo O (2016) Nasopharyngeal microbiota, host transcriptome, and disease severity in children with respiratory syncytial virus infection. Am J Respir Crit Care Med 194:1104-1115

37. de Vrese M, Rautenberg P, Laue C, Koopmans M, Herremans T, Schrezenmeir J (2005) Probiotic bacteria stimulate virus-specific neutralizing antibodies following a booster polio vaccination. Eur J Nutr 44:406-413

38. de Vrese M, Winkler P, Rautenberg P, Harder T, Noah C, Laue C, Ott S, Hampe J, Schreiber S, Heller K (2005) Effect of Lactobacillus gasseri PA 16/8, Bifidobacterium longum SP 07/3, B. bifidum MF 20/5 on common cold episodes: a double blind, randomized, controlled trial. Clin Nutr 24:481-491

39. de Vrese M, Winkler P, Rautenberg P, Harder T, Noah C, Laue C, Ott S, Hampe J, Schreiber S, Heller K, Schrezenmeir J (2005) Effect of Lactobacillus gasseri PA 16/8, Bifidobacterium longum SP 07/3, B. bifidum MF 20/5 on common cold episodes: a double blind, randomized, controlled trial. Clin Nutr (Edinburgh, Scotland) 24:481-491

40. de Wit E, van Doremalen N, Falzarano D, Munster VJ (2016) SARS and MERS: recent insights into emerging coronaviruses. Nat Rev Microbiol 14:523

41. Decaro N, Lorusso A (2020) Novel human coronavirus (SARSCoV-2): a lesson from animal coronaviruses. Veterinary Microbiol:108693

42. DeGruttola AK, Low D, Mizoguchi A, Mizoguchi E (2016) Current understanding of dysbiosis in disease in human and animal models. Inflamm Bowel Dis 22:1137-1150 
43. del Rio B, Dattwyler RJ, Aroso M, Neves V, Meirelles L, Seegers JF, Gomes-Solecki M (2008) Oral immunization with recombinant Lactobacillus plantarum induces a protective immune response in mice with Lyme disease. Clin Vaccine Immunol 15:1429-1435

44. Deng H, Yang S, Zhang Y, Qian K, Zhang Z, Liu Y, Wang Y, Bai Y, Fan H, Zhao X (2018) Bacteroides fragilis prevents clostridium difficile infection in a mouse model by restoring gut barrier and microbiome regulation. Front Microbiol 9:2976

45. Devadas K, Dhawan S (2006) Hemin activation ameliorates HIV-1 infection via heme oxygenase-1 induction. J Immunol $176: 4252-4257$

46. Di Pierro F (2020) A possible probiotic (S. salivarius K12) approach to improve oral and lung microbiotas and raise defenses against SARS-CoV-2. Minerva medica

47. Erturk-Hasdemir D, Kasper DL (2013) Resident commensals shaping immunity. Curr Opin Immunol 25:450-455

48. Espinoza JA, León MA, Céspedes PF, Gómez RS, CanedoMarroquín G, Riquelme SA, Salazar-Echegarai FJ, Blancou P, Simon T, Anegon I (2017) Heme oxygenase-1 modulates human respiratory syncytial virus replication and lung pathogenesis during infection. J Immunol 199:212-223

49. Fan Y-Y, Huang Z-T, Li L, Wu M-H, Yu T, Koup RA, Bailer RT, Wu C-Y (2009) Characterization of SARS-CoV-specific memory $\mathrm{T}$ cells from recovered individuals 4 years after infection. Adv Virol 154:1093-1099

50. FAO/WHO (2001) Evaluation of health and nutritional properties of powder milk and live lactic acid bacteria. pp 1-4

51. Feng Z, Wang Y, Qi W (2020) The small intestine, an underestimated site of SARS-CoV-2 infection: from red queen effect to probiotics. Preprints

52. Fijan S (2014) Microorganisms with claimed probiotic properties: an overview of recent literature. Int J Environ Res Public Health 11:4745-4767

53. Galani IE, Triantafyllia V, Eleminiadou E-E, Koltsida O, Stavropoulos A, Manioudaki M, Thanos D, Doyle SE, Kotenko SV, Thanopoulou $K$ (2017) Interferon- $\lambda$ mediates non-redundant front-line antiviral protection against influenza virus infection without compromising host fitness. Immunity 46(875-890):e876

54. Gao Q, Bao L, Mao H, Wang L, Xu K, Yang M, Li Y, Zhu L, Wang N, Lv Z (2020) Development of an inactivated vaccine candidate for SARS-CoV-2. Science

55. Glück U, Gebbers J-O (2003) Ingested probiotics reduce nasal colonization with pathogenic bacteria (Staphylococcus aureus, Streptococcus pneumoniae, and $\beta$-hemolytic streptococci). Am J Clin Nutr 77:517-520

56. Gonzalez-Ochoa G, Flores-Mendoza LK, Icedo-Garcia R, Gomez-Flores R, Tamez-Guerra P (2017) Modulation of rotavirus severe gastroenteritis by the combination of probiotics and prebiotics. Arch Microbiol 199:953-961

57. Goodarzi P, Mahdavi F, Mirzaei R, Hasanvand H, Sholeh M, Zamani F, Sohrabi M, Tabibzadeh A, Jeda AS, Niya MHK (2020) Coronavirus disease 2019 (COVID-19): Immunological approaches and emerging pharmacologic treatments. Int Immunopharmacol:106885

58. Goto Y, Uematsu S, Kiyono H (2016) Epithelial glycosylation in gut homeostasis and inflammation. Nat Immunol 17:1244

59. Gou W, Fu Y, Yue L, Chen G-d, Cai X, Shuai M, Xu F, Yi X, Chen H, Zhu YJ (2020) Gut microbiota may underlie the predisposition of healthy individuals to COVID-19. medRxiv

60. Gu J, Han B, Wang J (2020) COVID-19: gastrointestinal manifestations and potential fecal-oral transmission. Gastroenterology $158: 1518-1519$

61. Guan W-j, Ni Z-y, Hu Y, Liang W-h, Ou C-q, He J-x, Liu L, Shan H, Lei C-1, Hui DS (2020) Clinical characteristics of coronavirus disease 2019 in China. N Engl J Med 382:1708-1720
62. Guffee J, Fan W, Stein-Streilein J (1989) The Role of Natural Killer Cells in Early Defense to Influenza Virus Infection by the Intranasal Route1. Natural Killer Cells and Host Defense. Karger Publishers, pp 124-130

63. Guillemard E, Tondu F, Lacoin F, Schrezenmeir J (2010) Consumption of a fermented dairy product containing the probiotic Lactobacillus casei DN-114 001 reduces the duration of respiratory infections in the elderly in a randomised controlled trial. $\mathrm{Br}$ J Nutr 103:58-68

64. Guillemard E, Tondu F, Lacoin F, Schrezenmeir J (2010) Consumption of a fermented dairy product containing the probiotic Lactobacillus casei DN-114001 reduces the duration of respiratory infections in the elderly in a randomised controlled trial. $\mathrm{Br}$ J Nutr 103:58-68

65. Gutierrez-Castrellon P, Lopez-Velazquez G, Diaz-Garcia L, Jimenez-Gutierrez C, Mancilla-Ramirez J, Estevez-Jimenez J, Parra M (2014) Diarrhea in preschool children and Lactobacillus reuteri: a randomized controlled trial. Pediatrics 133:e904-e909

66. Hajeer AH, Balkhy H, Johani S, Yousef MZ, Arabi Y (2016) Association of human leukocyte antigen class II alleles with severe Middle East respiratory syndrome-coronavirus infection. Annals of thoracic medicine 11:211

67. Haller O, Kochs G, Weber F (2006) The interferon response circuit: induction and suppression by pathogenic viruses. Virology 344:119-130

68. Hardy H, Harris J, Lyon E, Beal J, Foey AD (2013) Probiotics, prebiotics and immunomodulation of gut mucosal defences: homeostasis and immunopathology. Nutrients 5:1869-1912

69. Hashiba T, Suzuki M, Nagashima Y, Suzuki S, Inoue S, Tsuburai T, Matsuse T, Ishigatubo Y (2001) Adenovirus-mediated transfer of heme oxygenase-1 cDNA attenuates severe lung injury induced by the influenza virus in mice. Gene Ther 8:1499-1507

70. Hayden FG (2004) Rhinovirus and the lower respiratory tract. Rev Med Virol 14:17-31

71. Hessle C, Hanson LÅ, Wold A (1999) Lactobacilli from human gastrointestinal mucosa are strong stimulators of IL-12 production. Clin Exp Immunol 116:276

72. Hill-Batorski L, Halfmann P, Neumann G, Kawaoka Y (2013) The cytoprotective enzyme heme oxygenase-1 suppresses Ebola virus replication. J Virol 87:13795-13802

73. Hill C, Guarner F, Reid G, Gibson GR, Merenstein DJ, Pot B, Morelli L, Canani RB, Flint HJ, Salminen S (2014) Expert consensus document: the international scientific association for probiotics and prebiotics consensus statement on the scope and appropriate use of the term probiotic. Nat Rev Gastroenterol Hepatol 11:506-514

74. Hinks TS (2016) Mucosal-associated invariant T cells in autoimmunity, immune-mediated diseases and airways disease. Immunology 148:1-12

75. Hojsak I, Snovak N, Abdović S, Szajewska H, Misak Z, Kolacek S (2010) Lactobacillus GG in the prevention of gastrointestinal and respiratory tract infections in children who attend day care centers: a randomized, double-blind, placebo-controlled trial. Clin Nutr (Edinburgh, Scotland) 29:312-316

76. Holshue ML, DeBolt C, Lindquist S, Lofy KH, Wiesman J, Bruce H, Spitters C, Ericson K, Wilkerson S, Tural A (2020) First case of 2019 novel coronavirus in the United States. New England Journal of Medicine

77. Huang C, Wang Y, Li X, Ren L, Zhao J, Hu Y, Zhang L, Fan G, Xu J, Gu X (2020) Clinical features of patients infected with 2019 novel coronavirus in Wuhan, China. The lancet 395:497-506

78. HwaMei Hospital UoCAoS (2020) Evaluation of the effect of taking Newgen beta-gluten probiotic composite powder to nutrition intervention of patients with novel coronavirus pneumonia (COVID-19) 
79. Ichinohe T, Pang IK, Kumamoto Y, Peaper DR, Ho JH, Murray TS, Iwasaki A (2011) Microbiota regulates immune defense against respiratory tract influenza A virus infection. Proc Natl Acad Sci 108:5354-5359

80. Insight $\mathrm{N}$ (2020) Biosearch Life launches probiotic COVID-19 trial, consumers move for gut health products.

81. Iwasaki A, Pillai PS (2014) Innate immunity to influenza virus infection. Nat Rev Immunol 14:315

82. Iwase T, Uehara Y, Shinji H, Tajima A, Seo H, Takada K, Agata T, Mizunoe Y (2010) Staphylococcus epidermidis Esp inhibits Staphylococcus aureus biofilm formation and nasal colonization. Nature 465:346-349

83. Jiang X, Hou X, Tang L, Jiang Y, Ma G, Li Y (2016) A phase trial of the oral Lactobacillus casei vaccine polarizes Th2 cell immunity against transmissible gastroenteritis coronavirus infection. Appl Microbiol Biotechnol 100:7457-7469

84. Kanauchi O, Andoh A, AbuBakar S, Yamamoto N (2018) Probiotics and paraprobiotics in viral infection: clinical application and effects on the innate and acquired immune systems. Curr Pharm Des 24:710-717

85. Kesson AM (2007) Respiratory virus infections. Paediatr Respir Rev 8:240-248

86. Kim HJ, Kim C-H, Ryu J-H, Kim M-J, Park CY, Lee JM, Holtzman MJ, Yoon J-H (2013) Reactive oxygen species induce antiviral innate immune response through IFN- $\lambda$ regulation in human nasal epithelial cells. Am J Respir Cell Mol Biol 49:855-865

87. Kim HJ, Jo A, Jeon YJ, An S, Lee K-M, Yoon SS, Choi JY (2019) Nasal commensal Staphylococcus epidermidis enhances interferon- $\lambda$-dependent immunity against influenza virus. Microbiome 7:80

88. Kim SR, Kim HJ, Im Kim D, Lee KB, Park HJ, Jeong JS, Cho SH, Lee YC (2015) Blockade of interplay between IL-17A and endoplasmic reticulum stress attenuates LPS-induced lung injury. Theranostics 5:1343

89. Kumpitsch C, Koskinen K, Schöpf V, Moissl-Eichinger C (2019) The microbiome of the upper respiratory tract in health and disease. BMC Biol 17:87

90. Kumpu M, Kekkonen R, Kautiainen H, Järvenpää S, Kristo A, Huovinen P, Pitkäranta A, Korpela R, Hatakka K (2012) Milk containing probiotic Lactobacillus rhamnosus GG and respiratory illness in children: a randomized, double-blind, placebo-controlled trial. Eur J Clin Nutr 66:1020-1023

91. Kumpu M, Kekkonen RA, Kautiainen H, Jarvenpaa S, Kristo A, Huovinen P, Pitkaranta A, Korpela R, Hatakka K (2012) Milk containing probiotic Lactobacillus rhamnosus GG and respiratory illness in children: a randomized, double-blind, placebo-controlled trial. Eur J Clin Nutr 66:1020-1023

92. Kumpu M, Lehtoranta L, Roivainen M, Ronkko E, Ziegler T, Soderlund-Venermo M, Kautiainen H, Jarvenpaa S, Kekkonen R, Hatakka K, Korpela R, Pitkaranta A (2013) The use of the probiotic Lactobacillus rhamnosus GG and viral findings in the nasopharynx of children attending day care. J Med Virol 85:1632-1638

93. Kumpu M, Lehtoranta L, Roivainen M, Rönkkö E, Ziegler T, Söderlund-Venermo M, Kautiainen H, Järvenpää S, Kekkonen R, Hatakka K (2013) The use of the probiotic Lactobacillus rhamnosus GG and viral findings in the nasopharynx of children attending day care. J Med Virol 85:1632-1638

94. Lal P, Ramachandran V, Goyal R, Sharma R (2007) Edible vaccines: current status and future. Indian J Med Microbiol 25:93

95. Lamers MM, Beumer J, van der Vaart J, Knoops K, Puschhof J, Breugem TI, Ravelli RB, van Schayck JP, Mykytyn AZ, Duimel HQ (2020) SARS-CoV-2 productively infects human gut enterocytes. Science
96. Langevin S, Pichon M, Smith E, Morrison J, Bent Z, Green R, Barker K, Solberg O, Gillet Y, Javouhey E (2017) Early nasopharyngeal microbial signature associated with severe influenza in children: a retrospective pilot study. J Gen Virol 98:2425-2437

97. Lehtoranta L, Pitkaranta A, Korpela R (2014) Probiotics in respiratory virus infections. Euro J Clin Microbiol Infect Dis 33:1289-1302

98. Lehtoranta L, Pitkäranta A, Korpela R (2014) Probiotics in respiratory virus infections. Eur J Clin Microbiol Infect Dis 33:1289-1302

99. Lei W-T, Shih P-C, Liu S-J, Lin C-Y, Yeh T-L (2017) Effect of probiotics and prebiotics on immune response to influenza vaccination in adults: a systematic review and meta-analysis of randomized controlled trials. Nutrients 9:1175

100. Leyer GJ, Li S, Mubasher ME, Reifer C, Ouwehand AC (2009) Probiotic effects on cold and influenza-like symptom incidence and duration in children. Pediatrics 124:e172-e179

101. Li G, Chen X, Xu A (2003) Profile of specific antibodies to the SARS-associated coronavirus. N Engl J Med 349:508-509

102. Li M-Y, Li L, Zhang Y, Wang X-S (2020) Expression of the SARS-CoV-2 cell receptor gene ACE2 in a wide variety of human tissues. Infect Dis Poverty 9:1-7

103. Li W, Zhang C, Sui J, Kuhn JH, Moore MJ, Luo S, Wong SK, Huang IC, Xu K, Vasilieva N (2005) Receptor and viral determinants of SARS-coronavirus adaptation to human ACE2. EMBO J 24:1634-1643

104. Li X, Geng M, Peng Y, Meng L, Lu S (2020) Molecular immune pathogenesis and diagnosis of COVID-19. J Pharmaceutical Anal

105. Liew FY, Russell SM, Brand CM (1979) Induction and characterization of delayed-type hypersensitivity to influenza virus in mice. Eur J Immunol 9:783-790

106. Lin J-S, Chiu Y-H, Lin N-T, Chu C-H, Huang K-C, Liao K-W, Peng K-C (2009) Different effects of probiotic species/strains on infections in preschool children: a double-blind, randomized, controlled study. Vaccine 27:1073-1079

107. Liu B, Han J, Cheng X, Yu L, Zhang L, Wang W, Ni L, Wei C, Huang Y, Cheng Z (2020) Reduced numbers of T cells and B cells correlates with persistent SARS-CoV-2 presence in nonsevere COVID-19 patients. Sci Rep 10:17718

108. Liu J, Wu P, Gao F, Qi J, Kawana-Tachikawa A, Xie J, Vavricka CJ, Iwamoto A, Li T, Gao GF (2010) Novel immunodominant peptide presentation strategy: a featured HLA-A* 2402-restricted cytotoxic T-lymphocyte epitope stabilized by intrachain hydrogen bonds from severe acute respiratory syndrome coronavirus nucleocapsid protein. J Virol 84:11849-11857

109. Liu M, Zhong Y, Chen J, Liu Y, Tang C, Wang X, Zhang Y, Wang P, Logan SM, Chen W (2020) Oral immunization of mice with a multivalent therapeutic subunit vaccine protects against Helicobacter pylori infection. Vaccine

110. Liu W, Ouyang X, Yang J, Liu J, Li Q, Gu Y, Fukata M, Lin T, He JC, Abreu M (2009) AP-1 activated by toll-like receptors regulates expression of IL-23 p19. J Biol Chem 284:24006-24016

111. Liu Y-S, Liu Q, Jiang Y-L, Yang W-T, Huang H-B, Shi C-W, Yang G-L, Wang C-F (2020) Surface-displayed porcine IFN- $\lambda 3$ in Lactobacillus plantarum inhibits porcine enteric coronavirus infection of porcine intestinal epithelial cells. J Microbiol Biotechnol 30:515-525

112. Liu Y-W, Liong M-T, Tsai Y-C (2018) New perspectives of Lactobacillus plantarum as a probiotic: the gut-heart-brain axis. J Microbiol 56:601-613

113. Luoto R, Ruuskanen O, Waris M, Kalliomäki M, Salminen S, Isolauri E (2014) Prebiotic and probiotic supplementation prevents rhinovirus infections in preterm infants: a randomized, placebo-controlled trial. J Allergy Clin Immunol 133:405-413 
114. Ma S, Wang L, Huang X, Wang X, Chen S, Shi W, Qiao X, Jiang Y, Tang L, Xu Y (2018) Oral recombinant Lactobacillus vaccine targeting the intestinal microfold cells and dendritic cells for delivering the core neutralizing epitope of porcine epidemic diarrhea virus. Microb Cell Fact 17:1-12

115. Ma W-T, Pang M, Fan Q-L, Chen D-K (2019) The commensal microbiota and viral infection: a comprehensive review. Front Immunol 10:1551

116. Maassen CB, van Holten-Neelen C, Balk F, den Bak-Glashouwer M-JH, Leer RJ, Laman JD, Boersma WJ, Claassen E (2000) Strain-dependent induction of cytokine profiles in the gut by orally administered Lactobacillus strains. Vaccine 18:2613-2623

117. Maassen CB, Boersma WJ, van Holten-Neelen C, Claassen E, Laman JD (2003) Growth phase of orally administered Lactobacillus strains differentially affects IgG1/IgG2a ratio for soluble antigens: implications for vaccine development. Vaccine 21:2751-2757

118. Makino S, Ikegami S, Kano H, Sashihara T, Sugano H, Horiuchi $\mathrm{H}$, Saito T, Oda M (2006) Immunomodulatory effects of polysaccharides produced by Lactobacillus delbrueckii ssp. bulgaricus OLL1073R-1. J Dairy Sci 89:2873-2881

119. Makino S, Ikegami S, Kume A, Horiuchi H, Sasaki H, Orii N (2010) Reducing the risk of infection in the elderly by dietary intake of yoghurt fermented with Lactobacillus delbrueckii ssp. bulgaricus OLL1073R-1. Br J Nutr 104:998-1006

120. Markowiak P, Śliżewska K (2017) Effects of probiotics, prebiotics, and synbiotics on human health. Nutrients 9:1021

121. Medicine S (2020) Stanford Medicine researchers lead clinical trial of interferon-lambda for COVID-19.

122. Millot JL, Aymard M, Bardol A (2002) Reduced efficiency of influenza vaccine in prevention of influenza-like illness in working adults: a 7 month prospective survey in EDF Gaz de France employees, in Rhône-Alpes, 1996-1997. Occup Med 52:281-292

123. Mirzaei R, Sadeghi J, Talebi M, Irajian G (2017) Prevalence of atlE, ica, mecA, and mupA Genes in Staphylococcus epidermidis Isolates. Infect Dis Clin Pract 25:37-40

124. Mirzaei R, Goodarzi P, Asadi M, Soltani A, Aljanabi HAA, Jeda AS, Dashtbin S, Jalalifar S, Mohammadzadeh R, Teimoori A (2020) Bacterial co-infections with SARS-CoV-2. IUBMB Life 72:2097-2111

125. Mirzaei R, Karampoor S, Sholeh M, Moradi P, Ranjbar R, Ghasemi F (2020) A contemporary review on pathogenesis and immunity of COVID-19 infection. Mol Biol Rep 47:5365-5376

126. Mirzaei R, Mahdavi F, Badrzadeh F, Hosseini-Fard SR, Heidary M, Jeda AS, Mohammadi T, Roshani M, Yousefimashouf R, Keyvani H (2020) The emerging role of microRNAs in the severe acute respiratory syndrome coronavirus 2 (SARS-CoV-2) infection. Int Immunopharmacol

127. Mirzaei R, Mahdavi F, Badrzadeh F, Hosseini-Fard SR, Heidary M, Jeda AS, Mohammadi T, Roshani M, Yousefimashouf R, Keyvani H (2020) The emerging role of microRNAs in the severe acute respiratory syndrome coronavirus 2 (SARS-CoV-2) infection. Int Immunopharmacol:107204-107204

128. Mirzaei R, Mohammadzadeh R, Mahdavi F, Badrzadeh F, Kazemi S, Ebrahimi M, Soltani F, Kazemi S, Jeda AS, Darvishmotevalli M (2020) Overview of the current promising approaches for the development of an effective severe acute respiratory syndrome coronavirus 2 (SARS-CoV-2) vaccine. Int immunopharmacol:106928

129. Mogensen TH (2009) Pathogen recognition and inflammatory signaling in innate immune defenses. Clin Microbiol Rev 22:240-273

130. Mohamadzadeh M, Olson S, Kalina WV, Ruthel G, Demmin GL, Warfield KL, Bavari S, Klaenhammer TR (2005) Lactobacilli activate human dendritic cells that skew T cells toward T helper 1 polarization. Proc Natl Acad Sci 102:2880-2885
131. Morais AH, Passos TS, Maciel BL, da Silva-Maia JK (2020) Can probiotics and diet promote beneficial immune modulation and purine control in coronavirus infection? Nutrients 12:1737

132. Mustafa AD, Kalyanasundram J, Sabidi S, Song AA-L, Abdullah M, Rahim RA, Yusoff K (2018) Proof of concept in utilizing in-trans surface display system of Lactobacillus plantarum as mucosal tuberculosis vaccine via oral administration in mice. BMC Biotechnol 18:63

133. Ogata K, An E, Shioi Y, Nakamura K, Luo S, Yokose N, Minami S, Dan K (2001) Association between natural killer cell activity and infection in immunologically normal elderly people. Clin Exp Immunol 124:392-397

134. Olivares M, Diaz-Ropero MP, Sierra S, Lara-Villoslada F, Fonolla J, Navas M, Rodriguez JM, Xaus J (2007) Oral intake of Lactobacillus fermentum CECT5716 enhances the effects of influenza vaccination. Nutrition (Burbank, Los Angeles County, Calif) 23:254-260

135. Olivares M, Díaz-Ropero MP, Sierra S, Lara-Villoslada F, Fonollá J, Navas M, Rodríguez JM, Xaus J (2007) Oral intake of Lactobacillus fermentum CECT5716 enhances the effects of influenza vaccination. Nutrition 23:254-260

136. Onoguchi K, Yoneyama M, Takemura A, Akira S, Taniguchi T, Namiki H, Fujita T (2007) Viral infections activate types I and III interferon genes through a common mechanism. J Biol Chem 282:7576-7581

137. Organization TWH (2020) Coronavirus disease (COVID-19) pandemic.

138. Organization WH (2020) Water, sanitation, hygiene, and waste management for the COVID-19 virus: interim guidance, 23 April 2020. World Health Organization

139. Pang IK, Iwasaki A (2011) Inflammasomes as mediators of immunity against influenza virus. Trends Immunol 32:34-41

140. Park M-K, Vu N, Kwon Y-M, Lee Y-T, Yoo S, Cho Y-H, Hong S-M, Hwang HS, Ko E-J, Jung Y-J (2013) Lactobacillus plantarum DK119 as a probiotic confers protection against influenza virus by modulating innate immunity. PloS one 8

141. Park SE (2020) Epidemiology, virology, and clinical features of severe acute respiratory syndrome -coronavirus-2 (SARSCoV-2; Coronavirus Disease-19). Clin Exp Pediatr 63:119-124

142. Pattemore PK, Jennings LC (2008) Epidemiology of respiratory infections. Pediatr Respir Med. https://doi.org/10.1016/ B978-032304048-8.50035-9

143. Perez-Lopez A, Behnsen J, Nuccio S-P, Raffatellu M (2016) Mucosal immunity to pathogenic intestinal bacteria. Nat Rev Immunol 16:135-148

144. Pestka S, Krause CD, Walter MR (2004) Interferons, interferon-like cytokines, and their receptors. Immunol Rev 202:8-32

145. Peters S, Rowbotham S, Chisholm A, Wearden A, Moschogianis S, Cordingley L, Baker D, Hyde C, Chew-Graham C (2011) Managing self-limiting respiratory tract infections: a qualitative study of the usefulness of the delayed prescribing strategy. Br J Gen Pract 61:e579-e589

146. Pickles RJ, DeVincenzo JP (2015) Respiratory syncytial virus (RSV) and its propensity for causing bronchiolitis. J Pathol 235:266-276

147. Pimentel-Nunes P, Soares JB, Roncon-Albuquerque R Jr, DinisRibeiro M, Leite-Moreira AF (2010) Toll-like receptors as therapeutic targets in gastrointestinal diseases. Expert Opin Ther Targets $14: 347-368$

148. Platform ICTR (2020) A prospective, multicenter, open-label, randomized, parallel-controlled trial for probiotics to evaluate efficacy and safety in patients infected with 2019 novel coronavirus pneumonia (COVID-19).

149. Pu F, Guo Y, Li M, Zhu H, Wang S, Shen X, He M, Huang C, He F (2017) Yogurt supplemented with probiotics can protect 
the healthy elderly from respiratory infections: a randomized controlled open-label trial. Clin Interv Aging 12:1223-1231

150. Qin C, Zhou L, Hu Z, Zhang S, Yang S, Tao Y, Xie C, Ma K, Shang K, Wang W (2020) Dysregulation of immune response in patients with COVID-19 in Wuhan, China. Clinical Infectious Diseases

151. Ramakrishnan VR, Feazel LM, Gitomer SA, Ir D, Robertson CE, Frank DN (2013) The microbiome of the middle meatus in healthy adults. PLoS ONE 8:e85507

152. Rasoul M, Rokhsareh M, Mohammad SM, Sajad K, Ahmadreza M (2019) The human immune system against Staphylococcus epidermidis. Critical Reviews ${ }^{\mathrm{TM}}$ in Immunology 39

153. Ren D-Y, Li C, Qin Y-Q, Yin R-L, Du S-W, Ye F, Liu H-F, Wang M-P, Sun Y, Li X (2013) Lactobacilli reduce chemokine IL-8 production in response to TNF- $\alpha$ and Salmonella challenge of Caco- 2 cells. BioMed research international 2013

154. Ren D, Li C, Qin Y, Yin R, Li X, Tian M, Du S, Guo H, Liu C, Zhu N (2012) Inhibition of Staphylococcus aureus adherence to Caco- 2 cells by lactobacilli and cell surface properties that influence attachment. Anaerobe 18:508-515

155. Ren D, Li C, Qin Y, Yin R, Du S, Ye F, Liu C, Liu H, Wang M, Li Y (2014) In vitro evaluation of the probiotic and functional potential of Lactobacillus strains isolated from fermented food and human intestine. Anaerobe 30:1-10

156. Ren D, Li C, Qin Y, Yin R, Du S, Liu H, Zhang Y, Wang C, Rong F, Jin N (2015) Evaluation of immunomodulatory activity of two potential probiotic Lactobacillus strains by in vivo tests. Anaerobe 35:22-27

157. Review KB (2020) Korean researchers found substance inhibiting COVID-19.

158. Rouse BT, Sehrawat S (2010) Immunity and immunopathology to viruses: what decides the outcome? Nat Rev Immunol 10:514-526

159. Ruane D, Do Y, Brane L, Garg A, Bozzacco L, Kraus T, Caskey M, Salazar A, Trumpheller C, Mehandru S (2016) A dendritic cell targeted vaccine induces long-term HIV-specific immunity within the gastrointestinal tract. Mucosal Immunol 9:1340-1352

160. Sallusto F, Lenig D, Förster R, Lipp M, Lanzavecchia A (1999) Two subsets of memory $\mathrm{T}$ lymphocytes with distinct homing potentials and effector functions. Nature 401:708-712

161. Saunders-Hastings PR, Krewski D (2016) Reviewing the History of Pandemic Influenza: Understanding Patterns of Emergence and Transmission. Pathogens 5:66

162. Savoie K (2000) Edible vaccine success. Nature Publishing Group

163. Scheppler L, Vogel M, Zuercher AW, Zuercher M, Germond J-E, Miescher SM, Stadler BM (2002) Recombinant Lactobacillus johnsonii as a mucosal vaccine delivery vehicle. Vaccine 20:2913-2920

164. Schiavi E, Gleinser M, Molloy E, Groeger D, Frei R, Ferstl R, Rodriguez-Perez N, Ziegler M, Grant R, Moriarty TF (2016) The surface-associated exopolysaccharide of Bifidobacterium longum 35624 plays an essential role in dampening host proinflammatory responses and repressing local TH17 responses. Appl Environ Microbiol 82:7185-7196

165. Seddik HA, Bendali F, Gancel F, Fliss I, Spano G, Drider D (2017) Lactobacillus plantarum and its probiotic and food potentialities. Probiotics Antimicrobial Proteins 9:111-122

166. Shakoor S, Rao A, Shahid N, Yaqoob A, Samiullah T, Latif A, Tabassum B, Khan M, Shahid A, Husnain T (2019) Role of oral vaccines as an edible tool to prevent infectious diseases. Acta Virol 63:245-252

167. Shanghai 10th People's Hospital TU (2020) A clinical study for probiotics in the regulation of intestinal function and microflora structure of novel coronavirus pneumonia (COVID-19)
168. Shi S-H, Yang W-T, Yang G-L, Zhang X-K, Liu Y-Y, Zhang L-J, Ye L-P, Hu J-T, Xing X, Qi C (2016) Lactobacillus plantarum vaccine vector expressing hemagglutinin provides protection against H9N2 challenge infection. Virus Res 211:46-57

169. Simoes EA, Cherian T, Chow J, Shahid-Salles SA, Laxminarayan R, John TJ (2006) Acute respiratory infections in children. Disease Control Priorities in Developing Countries 2nd edition. The International Bank for Reconstruction and Development/The World Bank

170. Singhal T (2020) A Review of Coronavirus Disease-2019 (COVID-19). Indian J Pediatr 87:281-286

171. Sirichokchatchawan W, Temeeyasen G, Nilubol D, Prapasarakul N (2018) Protective effects of cell-free supernatant and live lactic acid bacteria isolated from Thai pigs against a pandemic strain of porcine epidemic diarrhea virus. Probiotics Antimicrobial Proteins 10:383-390

172. Sun Y, Qian J, Xu X, Tang Y, Xu W, Yang W, Jiang Y, Yang G, Ding Z, Cong Y (2018) Dendritic cell-targeted recombinantLactobacilli induce DC activation and elicit specific immune responses against G57 genotype of avian $\mathrm{H} 9 \mathrm{~N} 2$ influenza virus infection. Vet Microbiol 223:9-20

173. Taghizadeh-Hesary F, Akbari H (2020) The powerful immune system against powerful COVID-19: a hypothesis. Med Hypotheses 140:109762-109762

174. Taipale T, Pienihäkkinen K, Isolauri E, Larsen C, Brockmann E, Alanen P, Jokela J, Söderling E (2011) Bifidobacterium animalis subsp. lactis BB-12 in reducing the risk of infections in infancy. Br J Nutr 105:409-416

175. Talbot HK, Falsey AR (2010) The diagnosis of viral respiratory disease in older adults. Clin Infect Dis 50:747-751

176. Tamura S-i, Kurata T (2004) Defense mechanisms against influenza virus infection in the respiratory tract mucosa. Jpn J Infect Dis 57:236-247

177. Tang F, Quan Y, Xin Z-T, Wrammert J, Ma M-J, Lv H, Wang T-B, Yang H, Richardus JH, Liu W (2011) Lack of peripheral memory B cell responses in recovered patients with severe acute respiratory syndrome: a six-year follow-up study. J Immunol 186:7264-7268

178. Tapiovaara L, Pitkaranta A, Korpela R (2016) Probiotics and the upper respiratory tract-a review. Pediatric Infect Dis 1(2573-0282): 100019

179. Taubenberger JK, Morens DM (2006) 1918 Influenza: the mother of all pandemics. Emerg Infect Dis 12:15-22

180. Teijaro JR (2016) Type I interferons in viral control and immune regulation. Curr Opin Virol 16:31-40

181. Tortorici MA, Veesler D (2019) Structural insights into coronavirus entry. Advances in virus research. Elsevier, pp 93-116

182. Tseng C-K, Lin C-K, Wu Y-H, Chen Y-H, Chen W-C, Young $\mathrm{K}-\mathrm{C}$, Lee J-C (2016) Human heme oxygenase 1 is a potential host cell factor against dengue virus replication. Sci Rep 6:32176

183. Tu X, Chong WP, Zhai Y, Zhang H, Zhang F, Wang S, Liu W, Wei M, Siu NHO, Yang H (2015) Functional polymorphisms of the CCL2 and MBL genes cumulatively increase susceptibility to severe acute respiratory syndrome coronavirus infection. J Infect 71:101-109

184. van Doorn HR, Yu H (2020) Viral Respiratory Infections. Hunter's Tropical Med Emerging Infect Dis:284-288

185. van Eeden C, Khan L, Osman MS, Cohen Tervaert JW (2020) Natural killer cell dysfunction and its role in COVID-19. Int J Mol Sci 21:6351

186. van Woensel JBM, van Aalderen WMC, Kimpen JLL (2003) Viral lower respiratory tract infection in infants and young children. BMJ 327:36-40 
187. Vandecandelaere I, Depuydt P, Nelis HJ, Coenye T (2014) Protease production by Staphylococcus epidermidis and its effect on Staphylococcus aureus biofilms. Pathogens Dis 70:321-331

188. Wald TG, Shult P, Krause P, Miller BA, Drinka P, Gravenstein $S$ (1995) A rhinovirus outbreak among residents of a long-term care facility. Ann Intern Med 123:588-593

189. Walls AC, Park Y-J, Tortorici MA, Wall A, McGuire AT, Veesler D (2020) Structure, function, and antigenicity of the SARSCoV-2 spike glycoprotein. Cell

190. Wan S, Yi Q, Fan S, Lv J, Zhang X, Guo L, Lang C, Xiao Q, Xiao K, Yi Z (2020) Characteristics of lymphocyte subsets and cytokines in peripheral blood of 123 hospitalized patients with 2019 novel coronavirus pneumonia (NCP). MedRxiv

191. Wan Y, Shang J, Graham R, Baric RS, Li F (2020) Receptor recognition by the novel coronavirus from Wuhan: an analysis based on decade-long structural studies of SARS coronavirus. J Virol 94

192. Wang F, Kream RM, Stefano GB (2020) An evidence based perspective on mRNA-SARS-CoV-2 vaccine development. Med Sci Monitor 26:e924700-924701

193. Wang F, Nie J, Wang H, Zhao Q, Xiong Y, Deng L, Song S, Ma Z, Mo P, Zhang Y (2020) Characteristics of peripheral lymphocyte subset alteration in COVID-19 pneumonia. J Infect Dis 221:1762-1769

194. Wang M, Fu T, Hao J, Li L, Tian M, Jin N, Ren L, Li C (2020) A recombinant Lactobacillus plantarum strain expressing the spike protein of SARS-CoV-2. Int J Biol Macromolecules

195. Wang S, Geng N, Zhou D, Qu Y, Shi M, Xu Y, Liu K, Liu Y, Liu J (2019) Oral immunization of chickens with recombinant Lactobacillus plantarum vaccine against early ALV-J infection. Front Immunol 10

196. Wang X, Wang L, Huang X, Ma S, Yu M, Shi W, Qiao X, Tang L, Xu Y, Li Y (2017) Oral delivery of probiotics expressing dendritic cell-targeting peptide fused with porcine epidemic diarrhea virus $\mathrm{COE}$ antigen: a promising vaccine strategy against PEDV. Viruses 9:312

197. Wang X, Wang L, Zheng D, Chen S, Shi W, Qiao X, Jiang Y, Tang L, Xu Y, Li Y (2018) Oral immunization with a Lactobacillus casei-based anti-porcine epidemic diarrhoea virus (PEDV) vaccine expressing microfold cell-targeting peptide Co1 fused with the COE antigen of PEDV. J Appl Microbiol 124:368-378

198. Wathelet MG, Lin CH, Parekh BS, Ronco LV, Howley PM, Maniatis T (1998) Virus infection induces the assembly of coordinately activated transcription factors on the IFN- $\beta$ enhancer in vivo. Mol Cell 1:507-518

199. Weiss SR, Navas-Martin S (2005) Coronavirus pathogenesis and the emerging pathogen severe acute respiratory syndrome coronavirus. Microbiol Mol Biol Rev 69:635-664

200. Weizman Z, Asli G, Alsheikh A (2005) Effect of a probiotic infant formula on infections in child care centers: comparison of two probiotic agents. Pediatrics 115:5-9

201. West NP, Horn PL, Pyne DB, Gebski VJ, Lahtinen SJ, Fricker PA, Cripps AW (2014) Probiotic supplementation for respiratory and gastrointestinal illness symptoms in healthy physically active individuals. Clin Nutr 33:581-587

202. West NP, Horn PL, Pyne DB, Gebski VJ, Lahtinen SJ, Fricker PA, Cripps AW (2014) Probiotic supplementation for respiratory and gastrointestinal illness symptoms in healthy physically active individuals. Clin Nutr (Edinburgh, Scotland) 33:581-587

203. Wieërs G, Belkhir L, Enaud R, Leclercq S, Philippart de Foy J-M, Dequenne I, de Timary P, Cani PD (2020) How probiotics affect the microbiota. Front Cell Infect Microbiol 9:454
204. Wong SH, Lui RN (2020) Covid-19 and the digestive system. 35:744-748

205. Wu F, Zhao S, Yu B, Chen Y-M, Wang W, Song Z-G, Hu Y, Tao Z-W, Tian J-H, Pei Y-Y (2020) A new coronavirus associated with human respiratory disease in China. Nature 579:265-269

206. Xu K, Cai H, Shen Y, Ni Q, Chen Y, Hu S, Li J, Wang H, Yu L, Huang H (2020) Management of corona virus disease-19 (COVID-19): the Zhejiang experience. Journal of Zhejiang University (medical science) 49:0-0

207. Xu K, Cai H, Shen Y, Ni Q, Chen Y, Hu S, Li J, Wang H, Yu L, Huang H, Qiu Y, Wei G, Fang Q, Zhou J, Sheng J, Liang T, Li L (2020) [Management of corona virus disease-19 (COVID-19): the Zhejiang experience]. Zhejiang da xue xue bao Yi xue ban = Journal of Zhejiang University Medical sciences 49:0

208. Yan F, Polk D (2011) Probiotics and immune health. Curr Opin Gastroenterol 27:496

209. Yang Y, Shen C, Li J, Yuan J, Yang M, Wang F, Li G, Li Y, Xing L, Peng L (2020) Exuberant elevation of IP-10, MCP-3 and IL-1ra during SARS-CoV-2 infection is associated with disease severity and fatal outcome. MedRxiv

210. Yuki K, Fujiogi M, Koutsogiannaki S (2020) COVID-19 pathophysiology: a review. Clin Immunol 215:108427-108427

211. Zaim S, Chong JH, Sankaranarayanan V, Harky A (2020) COVID-19 and Multi-Organ Response. Curr Probl Cardiol 45(8): 100618

212. Zeng Z-Q, Chen D-H, Tan W-P, Qiu S-Y, Xu D, Liang H-X, Chen M-X, Li X, Lin Z-S, Liu W-K, Zhou R (2018) Epidemiology and clinical characteristics of human coronaviruses OC43, 229E, NL63, and HKU1: a study of hospitalized children with acute respiratory tract infection in Guangzhou, China. Euro J Clin Microbiol Infect Dis 37:363-369

213. Zha L, Zhao H, Mohsen MO, Hong L, Zhou Y, Li Z, Yao C, Chen H, Liu X, Chang X (2020) Development of a COVID-19 vaccine based on the receptor binding domain displayed on virus-like particles. bioRxiv

214. Zhang N, Wang L, Deng X, Liang R, Su M, He C, Hu L, Su Y, Ren J, Yu F (2020) Recent advances in the detection of respiratory virus infection in humans. J Med Virol 92:408-417

215. Zhao J, Li K, Wohlford-Lenane C, Agnihothram SS, Fett C, Zhao J, Gale MJ, Baric RS, Enjuanes L, Gallagher T (2014) Rapid generation of a mouse model for Middle East respiratory syndrome. Proc Natl Acad Sci 111:4970-4975

216. Zhou P, Yang X-L, Wang X-G, Hu B, Zhang L, Zhang W, Si H-R, Zhu Y, Li B, Huang C-L (2020) A pneumonia outbreak associated with a new coronavirus of probable bat origin. Nature 579:270-273

217. Zhou Z, Hamming OJ, Ank N, Paludan SR, Nielsen AL, Hartmann R (2007) Type III interferon (IFN) induces a type I IFNlike response in a restricted subset of cells through signaling pathways involving both the Jak-STAT pathway and the mitogenactivated protein kinases. J Virol 81:7749-7758

218. Zou X, Chen K, Zou J, Han P, Hao J, Han Z (2020) Single-cell RNA-seq data analysis on the receptor ACE2 expression reveals the potential risk of different human organs vulnerable to 2019$\mathrm{nCoV}$ infection. Frontiers of medicine:1-8

Publisher's Note Springer Nature remains neutral with regard to jurisdictional claims in published maps and institutional affiliations. 